\title{
Synthesis of a Promising Immunosuppressant: FR252921
}

\author{
Dominique Amans, Véronique Bellosta and Janine Cossy* \\ Laboratoire de Chimie Organique, ESPCI-CNRS, 10 rue Vauquelin \\ 75231 Paris Cedex 05 - France
}

TABLE OF CONTENTS

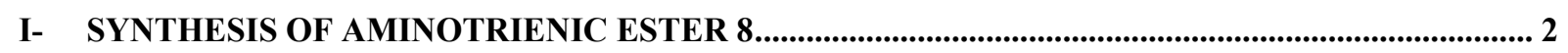

II- SYNTHESIS OF VINYL STANNANE 11 ......................................................................................... 5

III- SYNTHESIS OF CARBOXYLIC ACID S-17........................................................................... 7

IV- SYNTHESIS OF CARBOXYLIC ACID R-17 ......................................................................... 13

V- SYNTHESIS OF (2Z,4E,6E) STEREOISOMERS S-23 AND R-23 ................................................... 17

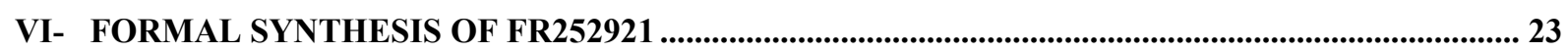

\section{General}

TLC was performed on Merck $60 \mathrm{~F}_{254}$ silica gel plates and visualized either with a UV lamp (254 nm), or by using a solution of $p$-anisaldehyde/sulfuric acid/acetic acid in EtOH followed by heating.

Flash chromatography was performed with Merck Geduran Si60 silica 251gel (40-63 UM).

Infrared (IR) spectra were recorded on a Perkin-Elmer 298 or on a Bruker TENSOR ${ }^{\mathrm{TM}} 27$ (IRFT), wave-numbers are indicated in $\mathrm{cm}^{-1} .{ }^{1} \mathrm{H}$ NMR spectra were recorded on a Bruker AVANCE 400 at $400 \mathrm{MHz}$ and data are reported as follows: chemical shift in ppm from tetramethylsilane as an internal standard, multiplicity $(\mathrm{s}=$ singlet, $\mathrm{d}=$ doublet, $\mathrm{t}=$ triplet, $\mathrm{q}=$ quartet, quint $=$ quintuplet, $\mathrm{m}=$ multiplet or overlap of non equivalent resonances), integration. ${ }^{13} \mathrm{C}$ NMR spectra were recorded on a Bruker AC 300 at $75 \mathrm{MHz}$ or on a Bruker AVANCE 400 at $100 \mathrm{MHz}$ and data are reported as follows: chemical shift in ppm from tetramethylsilane with the solvent as an internal indicator $\left(\mathrm{CDCl}_{3} \delta 77.0 \mathrm{ppm}\right)$, multiplicity with respect to proton (deduced from DEPT experiments, $\mathrm{s}=$ quaternary $\mathrm{C}, \mathrm{d}=\mathrm{CH}, \mathrm{t}=\mathrm{CH}_{2}$, $\mathrm{q}=\mathrm{CH}_{3}$ ). Mass spectra with electronic impact (MS) were recorded from a Hewlett-Packard tandem 5890A GC (12 m capillary column) - 5971 MS (70 eV). High resolution mass spectra 
(HRMS) were performed by the Groupe de Spectrométrie de Masse de l'Université Pierre et Marie Curie (Paris).

All the reactions were performed under an argon atmosphere.

\section{I- $\quad$ Synthesis of aminotrienic ester 8}

\section{(-)-(5R)- tert-Butyl-5-[(1S)-1-((3E,5E,7E)-8-methoxycarbonylocta-3,5,7-} trienylcarbamoyl)-ethyl]-2,2-dimethyloxazolidine-3-carboxylate (5):

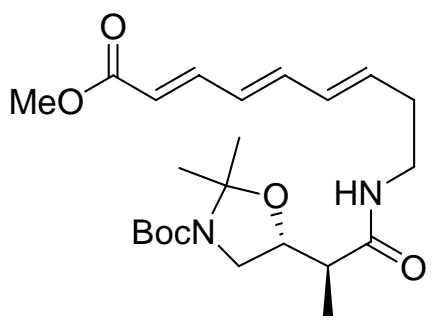

To a solution of carboxylic acid 4 (603 $\mathrm{mg}, 2.21 \mathrm{mmol}, 1.0$ equiv) and trienic amine 2 (480 mg, $2.65 \mathrm{mmol}, 1.2$ equiv) in anhydrous $\mathrm{CH}_{3} \mathrm{CN}(50 \mathrm{~mL})$, at $0{ }^{\circ} \mathrm{C}$, were successively added 1-hydroxybenzotriazole (358 mg, $2.65 \mathrm{mmol}, 1.2$ equiv), O-(1H-benzotriazole-1-yl)$N, N, N^{\prime}, N^{\prime}$-tetramethyluronium hexafluorophosphate $(1.0 \mathrm{~g}, 2.65 \mathrm{mmol}, 1.2$ equiv) and $N$ methylmorpholine ( $728 \mu \mathrm{L}, 6.62 \mathrm{mmol}, 3.0$ equiv). The solution was allowed to warm to $\mathrm{rt}$ and after stirring for $6 \mathrm{~h}$, the resulting brown mixture was hydrolyzed by addition of water ( 25 $\mathrm{mL}$ ). $\mathrm{CH}_{3} \mathrm{CN}$ was removed under reduced pressure and the resulting aqueous layer was extracted with EtOAc $(3 \times 30 \mathrm{~mL})$. The combined organic layers were successively washed with a saturated aqueous solution of $\mathrm{NaHCO}_{3}(30 \mathrm{~mL})$, a saturated aqueous solution of $\mathrm{NH}_{4} \mathrm{Cl}$ $(30 \mathrm{~mL})$ and brine $(30 \mathrm{~mL})$. The organic layer was dried over $\mathrm{MgSO}_{4}$, filtered and evaporated to dryness under reduced pressure. The residue thus obtained was purified by flash chromatography on silica gel (Petroleum ether/EtOAc 50:50) which provided the desired amide 5 (922 $\mathrm{mg}, 96 \%)$ as a waxy solid.

$\boldsymbol{R} \boldsymbol{f} \approx 0.2$ (Petroleum ether/EtOAc 50:50); $[\boldsymbol{\alpha}]^{\mathbf{2 0}}{ }_{\mathbf{D}}-4.5$ (c 1.36, MeOH); IR (film) : 3424, 3338, 2978, 2938, 1693, 1658, 1616, 1542, 1392, 1367, 1253, 1140, 1007, $839 \mathrm{~cm}^{-1} ;{ }^{1} \mathbf{H}$ NMR (CDCl $\left.)_{3}\right): \delta=7.29(\mathrm{dd}, 1 \mathrm{H}, J=15.2,11.2 \mathrm{~Hz}), 6.51(\mathrm{dd}, 1 \mathrm{H}, J=14.8, J=10.8 \mathrm{~Hz})$, 6.30-6.15 (m, 2H+NH), $5.87(\mathrm{~m}, 1 \mathrm{H}), 5.87(\mathrm{~d}, 1 \mathrm{H}, J=15.2 \mathrm{~Hz}), 4.09(\mathrm{~m}, 1 \mathrm{H}), 3.75(\mathrm{~s}, 3 \mathrm{H})$, 3.64 (br s, 1H), 3.37 (m, 2H), $3.11\left(\mathrm{t}_{\mathrm{app}}, 1 \mathrm{H}, J=9.9 \mathrm{~Hz}\right), 2.37$ (m, 3H, $\left.J=5.7 \mathrm{~Hz}\right), 1.56$ (br s, 3H), 1.51 (br s, 3H), 1.47 (s, 9H), 1.14 (br s, 3H); ${ }^{13} \mathbf{C} \mathbf{N M R}\left(\mathbf{C D C l}_{3}\right): \delta=173.2$ (s), 167.5 (s), 
152.2 and 151.8 (s), 144.6 (d), 140.4 (d), 136.1 (d), 131.9 (d), 128.8 (d), 120.4 (d), 94.0 and $93.5(\mathrm{~s}), 80.4$ and $79.8(\mathrm{~s}), 75.0(\mathrm{~d}), 51.5(\mathrm{q}), 49.6$ and $49.5(\mathrm{t}), 44.2$ and $44.0(\mathrm{~d}), 38.5(\mathrm{t})$, 33.1 (t), 28.3 (3q), 27.3, 26.2, 25.2 and 24.4 (2q), 13.4 (q); HRMS (CI $\left.{ }^{+}, \mathbf{N H}_{3}\right):$ Calcd for $\mathrm{C}_{23} \mathrm{H}_{37} \mathrm{O}_{6} \mathrm{~N}_{2}[\mathrm{M}+\mathrm{H}]^{+}$: 437.2652; Found: 437.2643.

(+)-Methyl (2E,4E,6E)- 9-[(2S,3R)-4-(tert-butoxycarbonylamino)-3-hydroxy-2methylbutanamido]nona-2,4,6-trienoate (6):

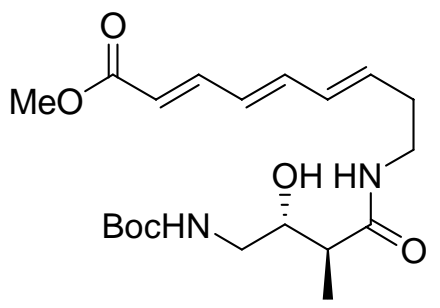

To a stirred solution of $N, O$-dimethyloxazolidine 5 (609 $\mathrm{mg}, 1.39 \mathrm{mmol}, 1.0$ equiv) in $\mathrm{MeOH}(10 \mathrm{~mL})$ was added $p$-toluenesulfonic acid $(132 \mathrm{mg}, 0.695 \mathrm{mmol}, 0.5$ equiv) in one portion. After stirring for $4 \mathrm{~h}$ at $\mathrm{rt}$, the reaction mixture was hydrolyzed by addition of a saturated aqueous solution of $\mathrm{NaHCO}_{3}(5 \mathrm{~mL})$ and the resulting aqueous layer was extracted with $\mathrm{Et}_{2} \mathrm{O}(3 \mathrm{x} 15 \mathrm{~mL})$. The combined organic layers were successively washed with a saturated aqueous solution of $\mathrm{NaHCO}_{3}(15 \mathrm{~mL})$, a saturated aqueous solution of $\mathrm{NH}_{4} \mathrm{Cl}(15$ $\mathrm{mL})$ and brine $(15 \mathrm{~mL})$. The organic layer was dried over $\mathrm{MgSO}_{4}$, filtered and evaporated in vacuo. The obtained residue was purified by flash chromatography on silica gel $\left(\mathrm{CH}_{2} \mathrm{Cl}_{2} / \mathrm{MeOH}\right.$ 98:2) which provided the desired $N$-Boc protected aminoalcohol 6 (451 mg, $82 \%)$ as a yellow foam.

$\boldsymbol{R f} \approx 0.25\left(\mathrm{CH}_{2} \mathrm{Cl}_{2} / \mathrm{MeOH} 98: 2\right) ;[\boldsymbol{\alpha}]^{\mathbf{2 0}}{ }_{\mathbf{D}}+11.3$ (c 1.04, $\left.\mathrm{CHCl}_{3}\right)$; IR (film) : 3307, 2978, 2932, 1714, 1662, 1639, 1620, 1534, 1247, 1233, 1171, 1137, 1002, $729 \mathrm{~cm}^{-1} ;{ }^{1} \mathbf{H}$ NMR (CDCl $): \delta$ $=7.29(\mathrm{dd}, 1 \mathrm{H}, J=15.2,11.2 \mathrm{~Hz}), 6.52(\mathrm{dd}, 1 \mathrm{H}, J=14.9,10.8 \mathrm{~Hz}), 6.40(\mathrm{br} \mathrm{m}, 1 \mathrm{H}, \mathrm{NH})$, $6.25(\mathrm{dd}, 1 \mathrm{H}, J=15.1,11.2 \mathrm{~Hz}), 6.21(\mathrm{dd}, 1 \mathrm{H}, J=15.3,10.8 \mathrm{~Hz}), 5.87(\mathrm{~d}, 1 \mathrm{H}, J=15.2 \mathrm{~Hz})$, $5.86(\mathrm{~m}, 1 \mathrm{H}), 5.0$ (br m, 1H, NH), $4.16(\mathrm{~m}, 1 \mathrm{H}), 3.75$ (s, 3H), 3.64 (br m, 1H, OH), 3.42-3.28 $(\mathrm{m}, 3 \mathrm{H}), 3.08(\mathrm{~m}, 1 \mathrm{H}), 2.42-2.28(\mathrm{~m}), 1.44(\mathrm{~s}, 9 \mathrm{H}), 1.25(\mathrm{~d}, 3 \mathrm{H}, J=7.1 \mathrm{~Hz}) ;{ }^{13} \mathbf{C} \mathbf{~ N M R}$ $\left(\mathbf{C D C l}_{3}\right): \delta=175.6$ (s), 167.5 (s), 156.8 (s), 144.7 (d), 140.5 (d), 135.9 (d), 131.9 (d), 128.7 (d), 120.2 (d), $79.6(\mathrm{~s}), 73.5$ (d), $51.5(\mathrm{q}), 45.0$ (t), 43.2 (d), $38.5(\mathrm{t}), 33.0(\mathrm{t}), 28.3(3 \mathrm{q}), 15.5$ (q); HRMS (CI+, $\mathbf{N H}_{3}$ ) : Calcd for $\mathrm{C}_{20} \mathrm{H}_{33} \mathrm{O}_{6} \mathrm{~N}_{2}[\mathrm{M}+\mathrm{H}]^{+}$: 397.2339; Found: 397.2343. 


\section{(+)-Methyl (2E,4E,6E)-9-[(2S,3R)-4-triisopropylsilanyloxyamino-2-methyl-3-}

\section{triisopropylsilanyloxy-butyrylamino]-nona-2,4,6-trienoate (7):}

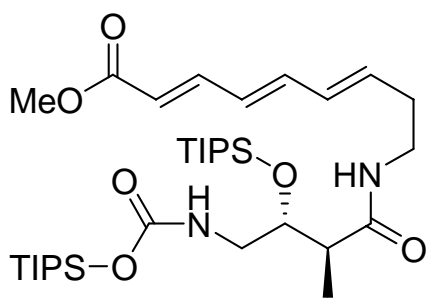

To a stirred solution of aminoalcohol 6 (178 mg, 0.449 mmol, 1.0 equiv) in $\mathrm{CH}_{2} \mathrm{Cl}_{2}$ (5 $\mathrm{mL})$ at $0{ }^{\circ} \mathrm{C}$ were successively added 2,6-lutidine (209 $\mu \mathrm{L}, 1.80 \mathrm{mmol}, 4.0$ equiv) and triisopropylsilyl trifluoromethanesulfonate $(241 \mu \mathrm{L}, 0.898 \mathrm{mmol}, 2.0$ equiv). The resulting solution was allowed to warm to $\mathrm{rt}$ and stirring was carried on for $1 \mathrm{~h}$. The reaction was quenched by addition of a saturated aqueous solution of $\mathrm{NH}_{4} \mathrm{Cl}(5 \mathrm{~mL})$, the layers were separated and the aqueous phase was extracted with $\mathrm{Et}_{2} \mathrm{O}(3 \times 15 \mathrm{~mL})$. The combined organic layers were washed with brine $(15 \mathrm{~mL})$, dried over $\mathrm{MgSO}_{4}$, filtered and concentrated in vacuo. Purification of the residue by flash chromatography on silica gel (Petroleum ether/EtOAc: 80/20) provided the protected aminoalcohol $7(293 \mathrm{mg}, 100 \%)$ as a viscous colorless oil.

$\boldsymbol{R f} \approx 0.25$ (Petroleum ether/EtOAc : 70/30); $[\boldsymbol{\alpha}]^{\mathbf{2 0}}{ }_{\mathbf{D}}+15.5$ (c $\left.0.83, \mathrm{CHCl}_{3}\right) ; \mathbf{I R}($ film) : 3349 , 2942, 2865, 1698, 1650, 1618, 1509, 1462, 1255, 1136, 1103, 1003, $882 \mathrm{~cm}^{-1} ;{ }^{1} \mathbf{H}$ NMR $\left(\mathbf{C D C l}_{3}\right): \delta=7.28(\mathrm{dd}, 1 \mathrm{H}, J=15.2,11.2 \mathrm{~Hz}), 6.49(\mathrm{dd}, 1 \mathrm{H}, J=14.9,10.8 \mathrm{~Hz}), 6.34(\mathrm{br} \mathrm{t}$, $1 \mathrm{H}, J=5.6 \mathrm{~Hz}, \mathrm{NH}), 6.22(\mathrm{dd}, 1 \mathrm{H}, J=14.9,11.2 \mathrm{~Hz}), 6.17(\mathrm{dd}, 1 \mathrm{H}, J=15.2,10.8 \mathrm{~Hz}), 5.85$ $(\mathrm{d}, 1 \mathrm{H}, J=15.2 \mathrm{~Hz}), 5.84(\mathrm{~m}, 1 \mathrm{H}), 5.08(\mathrm{~m}, 1 \mathrm{H}, \mathrm{NH}), 4.06(\mathrm{~m}, 1 \mathrm{H}), 3.73(\mathrm{~s}, 3 \mathrm{H}), 3.45(\mathrm{~m}$, 1H), $3.38(\mathrm{~m}, 1 \mathrm{H}), 3.29(\mathrm{~m}, 1 \mathrm{H}), 3.08(\mathrm{ddd}, 1 \mathrm{H}, J=11.8,6.9,4.8 \mathrm{~Hz}), 2.48(\mathrm{~m}, 1 \mathrm{H}), 2.35$ (qapp, 2H, $J=6.8 \mathrm{~Hz}), 1.27(\mathrm{~m}, 6 \mathrm{H}), 1.19(\mathrm{~d}, 3 \mathrm{H}, J=7.5 \mathrm{~Hz}), 1.09-1.04(\mathrm{~m}, 36 \mathrm{H}) ;{ }^{13} \mathbf{C} \mathbf{N M R}$ (CDCl $\left.\mathbf{C}_{3}\right): \delta=174.1$ (s), 167.5 (s), 155.0 (s), 144.6 (d), 140.4 (d), 136.0 (d), 132.0 (d), 128.8 (d), $120.3(\mathrm{~d}), 73.0$ (d), 51.5 (q), 45.1 (d), 44.7 (t), $38.4(\mathrm{t}), 33.1(\mathrm{t}), 18.2(6 \mathrm{q}), 17.8(6 \mathrm{q}), 14.7$ (q), 12.4 (3d), 12.1 (3d); HRMS (ESI) : Calcd for $\mathrm{C}_{34} \mathrm{H}_{64} \mathrm{O}_{6} \mathrm{~N}_{2} \mathrm{NaSi}_{2}[\mathrm{M}+\mathrm{Na}]^{+}:$675.4195; Found: 675.4200 . 


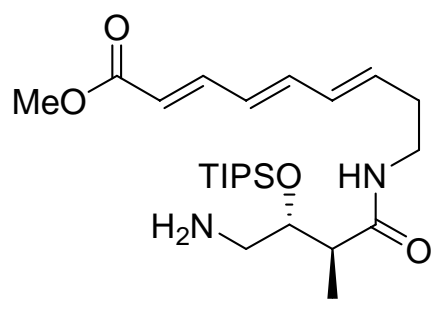

To a stirred solution of TIPS-carbamate 7 (196 mg, $0.300 \mathrm{mmol}, 1.0$ equiv) in anhydrous $\mathrm{CH}_{2} \mathrm{Cl}_{2}(8 \mathrm{~mL})$ at $0{ }^{\circ} \mathrm{C}$ was added trifluoracetic acid $(2 \mathrm{~mL})$ dropwise. The resulting brown mixture was allowed to warm to rt, and after $45 \mathrm{~min}$ of stirring, the solution was concentrated in vacuo. The ammonium trifluoroacetate thus obtained was diluted with $\mathrm{CHCl}_{3}(10 \mathrm{~mL})$, treated by a saturated aqueous solution of $\mathrm{Na}_{2} \mathrm{CO}_{3}(10 \mathrm{~mL})$ and the aqueous layer was vigorously extracted with $\mathrm{CHCl}_{3}(3 \times 10 \mathrm{~mL})$. The combined organic layers were washed with brine $(20 \mathrm{~mL})$, dried over $\mathrm{MgSO}_{4}$, filtered and concentrated under reduced pressure to provide the corresponding free amine $\mathbf{8}$ (136 $\mathrm{mg}$, quantitative) as a viscous brown oil, which was used in the next step without further purification.

\section{II- Synthesis of vinyl stannane 11}

\section{(E)-1-Iodonon-1-ene (10):}

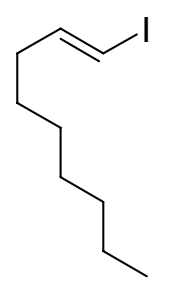

To a stirred solution of $\mathrm{Cp}_{2} \mathrm{ZrCl}_{2}(643 \mathrm{mg}, 2.2 \mathrm{mmol}, 1.1$ equiv) in anhydrous THF (5 $\mathrm{mL}$ ) was slowly added a solution of DIBAL-H (313 mg, $2.2 \mathrm{mmol}, 1.1$ equiv) in anhydrous THF $(1 \mathrm{~mL})$ at $0{ }^{\circ} \mathrm{C}$ under argon. After stirring the resulting white suspension for $30 \mathrm{~min}$ at $0{ }^{\circ} \mathrm{C}$, a solution of non-1-yne $(248 \mathrm{mg}, 2.0 \mathrm{mmol}, 1.0$ equiv) in THF (1 mL) was added dropwise. The reaction mixture was allowed to warm to $\mathrm{rt}$ and stirred until the obtention of a homogeneous solution ( $\mathrm{ca} 45 \mathrm{~min}$ ), and was then cooled to $-78{ }^{\circ} \mathrm{C}$. A solution of $\mathrm{I}_{2}(660 \mathrm{mg}$, 
$2.6 \mathrm{mmol}, 1.3$ equiv) in THF ( $3 \mathrm{~mL})$ was added dropwise to the previous solution, and after $30 \mathrm{~min}$ at $-78{ }^{\circ} \mathrm{C}$, the reaction mixture was hydrolyzed with $\mathrm{HCl} 1 \mathrm{M}(5 \mathrm{~mL})$. The aqueous layer was extracted with $\mathrm{Et}_{2} \mathrm{O}(3 \times 20 \mathrm{~mL})$, and the combined organic phases were successively washed with a saturated aqueous solution of $\mathrm{NaHCO}_{3}(20 \mathrm{~mL})$, a saturated aqueous solution of $\mathrm{Na}_{2} \mathrm{~S}_{2} \mathrm{O}_{3}(20 \mathrm{~mL})$, and brine $(20 \mathrm{~mL})$ followed by drying over $\mathrm{MgSO}_{4}$, filtration and concentration in vacuo. Purification of the residue by flash chromatography on silica gel (Hexanes: 100\%) provided the desired (E)-vinyl iodide 10 (449 $\mathrm{mg}, 89 \%$ ) as a colorless oil.

$\boldsymbol{R} \boldsymbol{f} \approx 0.9$ (Petroleum ether); IR (film): 2921, 2852, 1679, 1605, 1458, 1377, 1210, 1196, 944, $722 \mathrm{~cm}^{-1} ;{ }^{1} \mathbf{H}$ NMR $\left(\mathbf{C D C l}_{3}\right): \delta=6.51(\mathrm{dt}, 1 \mathrm{H}, J=14.3,7.2 \mathrm{~Hz}), 5.97(\mathrm{dt}, 1 \mathrm{H}, J=14.3,1.4$ $\mathrm{Hz}), 2.05(\mathrm{~m}, 2 \mathrm{H}), 1.38(\mathrm{~m}, 2 \mathrm{H}), 1.32-1.22(\mathrm{~m}, 8 \mathrm{H}), 0.88$ (br t, $3 \mathrm{H}, J=6.8 \mathrm{~Hz}) ;{ }^{13} \mathbf{C} \mathbf{~ N M R}$ $\left(\mathbf{C D C l}_{3}\right): \delta=146.8(\mathrm{~d}), 74.3(\mathrm{~s}), 36.1(\mathrm{t}), 31.8(\mathrm{t}), 29.2(\mathrm{t}), 29.0(\mathrm{t}), 28.4(\mathrm{t}), 22.7(\mathrm{t}), 14.1(\mathrm{t})$; MS (EI, $70 \mathrm{eV)}:$ m/z (\%): 253 (7), 252 (68), 167 (9), 166 (36), 154 (30), 83 (60), 70 (16), 69 (100), 67 (10), 57 (19), 56 (19), 55 (60), 54 (10), 53 (10).

\section{Tributyl[(E)-non-1-enyl]stannane (11):}

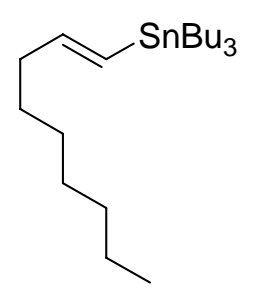

To a stirred solution of (E)-1-iodonon-1ene 10 (500 mg, $1.98 \mathrm{mmol}, 1.0$ equiv) in anhydrous $\mathrm{Et}_{2} \mathrm{O}(5 \mathrm{~mL})$ at $-78{ }^{\circ} \mathrm{C}$ was added tert-BuLi $(2.56 \mathrm{~mL}, 1.7 \mathrm{M}$ in pentane, 4.36 mmol, 2.2 equiv) dropwise. After stirring at this temperature for $45 \mathrm{~min}, \mathrm{Bu}_{3} \mathrm{SnCl}(537 \mu \mathrm{L}$, $1.98 \mathrm{mmol}, 1.0$ equiv) was slowly added dropwise and the solution was allowed to warm to rt. After stirring for further $45 \mathrm{~min}$, the reaction mixture was hydrolyzed with an aqueous saturated solution of $\mathrm{NH}_{4} \mathrm{Cl}(15 \mathrm{~mL})$ and the layers were separated. The aqueous phase was extracted with $\mathrm{Et}_{2} \mathrm{O}(3 \times 15 \mathrm{~mL})$ and the combined organic layers were washed with brine (15 $\mathrm{mL}$ ), dried over $\mathrm{MgSO}_{4}$, filtered and concentrated under reduced pressure. Purification of the crude residue by flash chromatography on silica gel (Hexanes/Et $t_{3} \mathrm{~N}$ : 99:1) provided the 
desired alkenyl stannane 11 (779 mg, 95\%) as a colorless oil, contaminated by unidentified stannylated impurities.

$\boldsymbol{R} \boldsymbol{f} \approx 0.95$ (Petroleum ether); IR (film) : 2954, 2920, 2844, 1599, 1463, 1376, 1071, 987, 960, 873, 863, 685, $659 \mathrm{~cm}^{-1} ;{ }^{1} \mathbf{H}$ NMR (CDCl $): \delta=5.95(\mathrm{dt}, 1 \mathrm{H}, J=18.9,5.9 \mathrm{~Hz}), 5.86(\mathrm{~d}, 1 \mathrm{H}, J$ $=18.9 \mathrm{~Hz}), 2.13\left(\mathrm{q}_{\mathrm{app}}, 2 \mathrm{H}, J=7.1 \mathrm{~Hz}\right), 1.54-1.45(\mathrm{~m}, 4 \mathrm{H}), 1.36-1.26(\mathrm{~m}, 12 \mathrm{H}), 0.92-0.86(\mathrm{~m}$, 24H); ${ }^{13}$ C NMR (CDCl $): \delta=149.9$ (d), 126.9 (d), 37.9 (t), 31.9 (t), 30.8 (2t), 29.3 (t), 29.1 (3t), 27.3 (3t), 22.7 (t), 14.1 (q), 13.7 (3q), 9.4 (3t); HRMS (ESI) : Calcd for $\mathrm{C}_{21} \mathrm{H}_{45} \mathrm{Sn}$ $[\mathrm{M}+\mathrm{H}]^{+}:$415.2536; Found: 415.2734.

\section{III- Synthesis of carboxylic acid (S-17)}

\section{(-)-tert-Butyl-(S)-\{1-[(E)-2-iodo-1-methylvinyl]-but-3-enyloxy\}-dimethylsilane (14) ${ }^{1}$ :}

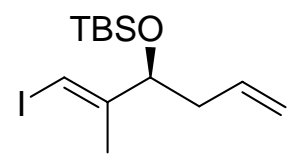

To a stirred solution of (E)-3-iodo-2-methylprop-2-en-1-ol 12 (3.80 g, 19.2 mmol, 1.0 equiv) in $\mathrm{CH}_{2} \mathrm{Cl}_{2}(120 \mathrm{~mL})$ at $\mathrm{rt}$ was added $\mathrm{MnO}_{2}(33 \mathrm{~g}, 384 \mathrm{mmol}, 20$ equiv) in one portion. After stirring vigorously the resulting dark mixture for $48 \mathrm{~h}$, Celite ${ }^{\circledR}$ was added and the heterogeneous mixture was then filterered through a plug of Celite ${ }^{\circledR}$ to remove the manganese salts. $\mathrm{CH}_{2} \mathrm{Cl}_{2}$ was removed under reduced pressure, thus affording the crude $\alpha, \beta$-unsaturated aldehyde 13 (3.31 g, 87\%) as a brown oil which was used in the next step without further purification.

To a stirred solution of cyclopentadienyl[(4R,trans)-2,2-dimethyl- $\alpha, \alpha, \alpha^{\prime}, \alpha^{\prime}-$ tetraphenyl-1,3-dioxolane-4,5-dimethanolato-O,O']titanium chloride $(8.1 \mathrm{~g}, 13.3 \mathrm{mmol}, 1.3$ equiv) in anhydrous $\mathrm{Et}_{2} \mathrm{O}(130 \mathrm{~mL})$ at $0{ }^{\circ} \mathrm{C}$, was added dropwise allylmagnesium chloride $(2$ $\mathrm{M}$ in THF, $5.6 \mathrm{~mL}, 11.2 \mathrm{mmol}, 1.1$ equiv). After $2 \mathrm{~h}$ at $0{ }^{\circ} \mathrm{C}$, the orange reaction mixture was cooled to $-78{ }^{\circ} \mathrm{C}$ and a solution of crude (E)-3-iodo-2-methylacrylaldehyde 13 (2 g, 10.2

\footnotetext{
${ }^{1}$ Nicolaou, K. C.; King, N; P.; Finlay, M. R. V.; He, Y.; Roschangar, F.; Vourloumis, D.; Vallberg, H.; Sarabia, F.; Ninkovic, S.; Hepworth, D. Bioorg. Med. Chem. 1999, 7, 665-697
} 
mmol, 1.0 equiv) in $\mathrm{Et}_{2} \mathrm{O}(30 \mathrm{~mL})$ was added dropwise via cannula. After $5 \mathrm{~h}$ at $-78^{\circ} \mathrm{C}$, the reaction was quenched by addition of a $45 \%$ aqueous $\mathrm{NH}_{4} \mathrm{~F}$ solution $(20 \mathrm{~mL})$. The reaction mixture was stirred for $12 \mathrm{~h}$ at $\mathrm{rt}$ and then filtered over Celite ${ }^{\circledR}$. The layers were separated and the aqueous phase was extracted with ether $(3 \times 100 \mathrm{~mL})$. The combined organic extracts were washed with brine $(100 \mathrm{~mL})$, dried over $\mathrm{MgSO}_{4}$, filtered and concentrated in vacuo. The residue was then diluted with pentane $(50 \mathrm{~mL})$ and filtered to remove (4R,trans)-2,2dimethyl- $\alpha, \alpha, \alpha^{\prime}, \alpha^{\prime}$-tetraphenyl-1,3-dioxolane-4,5-dimethanol. After removal of pentane under reduced pressure, purification of the residue by flash chromatography on silica gel (Toluene/EtOAc: 98/2 to 90/10) provided the desired enantioenriched homoallylic alcohol $(1.75 \mathrm{~g}, 72 \%)$ as a colorless oil.

To a stirred solution of the previously obtained (S,E)-1-iodo-2-methylhexa-1,5-dien-3ol (1.1 g, $4.62 \mathrm{mmol}, 1.0$ equiv) in $\mathrm{CH}_{2} \mathrm{Cl}_{2}(50 \mathrm{~mL})$ at $-78^{\circ} \mathrm{C}$ were added 2,6-lutidine (1.22 $\mathrm{mL}, 10.55 \mathrm{mmol}, 2.5$ equiv) and tert-butyldimethylsilyl trifluromethanesulfonate $(2.12 \mathrm{~mL}$, $9.24 \mathrm{mmol}, 2.0$ equiv). After $1 \mathrm{~h}$ of stirring at $-78^{\circ} \mathrm{C}$, the reaction mixture was hydrolyzed by adding a saturated aqueous solution of $\mathrm{NH}_{4} \mathrm{Cl}(20 \mathrm{~mL})$. The layers were separated and the aqueous phase was extracted with $\mathrm{Et}_{2} \mathrm{O}(3 \times 30 \mathrm{~mL})$. The combined organic layers were washed with brine $(30 \mathrm{~mL})$, dried over $\mathrm{MgSO}_{4}$, filtered and concentrated in vacuo. Purification of the residue by flash chromatography on silica gel (Hexanes: 100\%) provided the desired TBS-protected homoallylic alcohol $14(1.43 \mathrm{~g}, 88 \%)$ as a colorless oil. The physical and spectroscopic data of $\mathbf{1 4}$ were in accordance with those reported in the literature. $^{1}$

$\boldsymbol{R} \boldsymbol{f} \approx 0.5$ (Petroleum ether); $[\boldsymbol{\alpha}]^{\mathbf{2 0}}{ }_{\mathrm{D}}-17.7$ (c 1.05, $\left.\mathrm{CHCl}_{3}\right)\left\{\operatorname{litt}^{1}[\alpha]^{20}{ }_{\mathrm{D}}-17.5\right.$ (c 1.65, $\left.\left.\mathrm{CHCl}_{3}\right)\right\}$; IR (film) : 2926, 2855, 1740, 1462, 1377, 1253, 1168, 1086, 837, $778 \mathrm{~cm}^{-1} ;{ }^{1} \mathbf{H}$ NMR $\left(\mathbf{C D C l}_{3}\right): \delta=6.15(\mathrm{~m}, 1 \mathrm{H}), 5.70(\mathrm{~m}, 1 \mathrm{H}), 5.04(\mathrm{~m}, 1 \mathrm{H}), 5.01(\mathrm{br} \mathrm{s}, 1 \mathrm{H}), 4.16\left(\mathrm{t}_{\mathrm{app}}, 1 \mathrm{H}\right.$, $J=6.0 \mathrm{~Hz}$ ), 2.32-2.17 (m, 2H), 1.77 (br d, 3H, $J=1.0 \mathrm{~Hz}), 0.88$ (s, 9H), 0.03 (s, 3H), -0.01 (s, $3 \mathrm{H})$. 


\section{(-)-(E)-(S)-3-(tert-Butyldimethylsilanyloxy)-5-iodo-4-methylpent-4-enoic acid:}

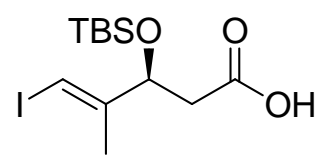

To a stirred solution of alkene $14(1.52 \mathrm{~g}, 4.31 \mathrm{mmol}, 1.0$ equiv $)$ in a tert$\mathrm{BuOH} / \mathrm{THF} /$ water mixture $(5 / 5 / 1,20 \mathrm{~mL})$ at $0{ }^{\circ} \mathrm{C}$, were added $N$-methylmorpholine $N$-oxide (555 g, 4.7 mmol, 1.1 equiv) and osmium tetroxide (4 wt\% in $\mathrm{H}_{2} \mathrm{O}, 262 \mu \mathrm{L}, 0.043 \mathrm{mmol}, 0.01$ equiv). After $18 \mathrm{~h}$ of stirring at $\mathrm{rt}$, the reaction was quenched by addition of a saturated aqueous solution of $\mathrm{Na}_{2} \mathrm{~S}_{2} \mathrm{O}_{3}(10 \mathrm{~mL})$ and the resulting mixture was allowed to stir for $1 \mathrm{~h}$. The aqueous layer was extracted with $\mathrm{Et}_{2} \mathrm{O}(3 \times 20 \mathrm{~mL})$ and the combined organic layers were washed with brine $(30 \mathrm{~mL})$, dried over $\mathrm{MgSO}_{4}$, filtered and concentrated under reduced pressure. The obtained crude 1,2-diol was used in the next step without further purification.

To a stirred solution of the obtained 1,2-diol in a $\mathrm{MeOH} / \mathrm{H}_{2} \mathrm{O}$ mixture $(2 / 1,45 \mathrm{~mL})$ was added sodium periodate in one portion $(5.53 \mathrm{~g}, 25.86 \mathrm{mmol}, 6.0$ equiv) at $\mathrm{rt}$. The resulting white slurry was stirred for $45 \mathrm{~min}$ and was subsequently quenched by addition of water $(50 \mathrm{~mL})$. The aqueous phase was extracted with $\mathrm{CH}_{2} \mathrm{Cl}_{2}(3 \times 50 \mathrm{~mL})$ and the combined organic layers were washed with brine $(50 \mathrm{~mL})$, dried over $\mathrm{MgSO}_{4}$, filtered and concentrated in vacuo. The resulting crude aldehyde was used in the next step without further purification.

To a stirred solution of the obtained crude aldehyde in a tert- $\mathrm{BuOH} / \mathrm{H}_{2} \mathrm{O}$ mixture $(7 / 2$, $50 \mathrm{~mL}$ ) were successively added 2-methyl-2-butene (2.93 mL, $27.68 \mathrm{mmol}, 10$ equiv), $\mathrm{NaH}_{2} \mathrm{PO}_{4} \cdot \mathrm{H}_{2} \mathrm{O}$ (4.75 g, 30.47 mmol, 11 equiv) and $\mathrm{NaClO}_{2}$ (1.5 g, 16.62 mmol, 6 equiv) at rt. After stirring for $12 \mathrm{~h}$, the reaction mixture was hydrolyzed by addition of an aqueous solution of $\mathrm{HCl} 1 \mathrm{M}(25 \mathrm{~mL})$, and the aqueous layer was extracted with $\mathrm{Et}_{2} \mathrm{O}(3 \times 50 \mathrm{~mL})$. The combined organic layers were washed with brine $(50 \mathrm{~mL})$, dried over $\mathrm{MgSO}_{4}$, filtered and concentrated under reduced pressure. Purification of the residue by flash chromatography on silica gel (Petroleum ether/EtOAc: 90/10) provided the desired carboxylic acid (977 mg, 61\% over 3 steps) as a viscous colorless oil which crystallized upon standing at $-20{ }^{\circ} \mathrm{C}$ (white solid).

$\boldsymbol{R} \boldsymbol{f} \approx 0.1$ (Petroleum ether/EtOAc 80:20); $[\boldsymbol{\alpha}]^{\mathbf{2 0}}{ }_{\mathbf{D}}-23.6$ (c 1.35, $\mathrm{CHCl}_{3}$ ); IR (film) : 2954,

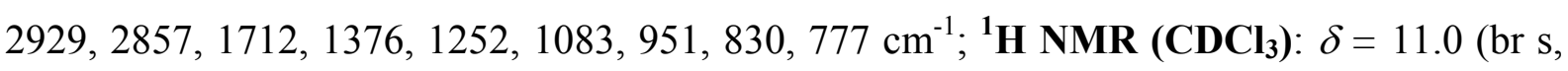
1H), 6.33 (br s, 1H), 4.65 (dd, 1H, $J=8.8,4.0 \mathrm{~Hz}), 2.58$ (dd, 1H, J=14.9, 8.9 Hz), 2.47 (dd, 
$1 \mathrm{H}, J=14.8,4.2 \mathrm{~Hz}), 1.80\left(\right.$ br s, 3H), 0.85 (s, 9H), 0.04 (s, 3H), -0.01 (s, 3H); ${ }^{13} \mathbf{C ~ N M R}$ $\left(\mathbf{C D C l}_{3}\right): \delta=177.0$ (s), 148.8 (s), 79.2 (d), 73.9 (d), 41.9 (t), $25.6(3 \mathrm{q}), 19.3$ (q), 18.1 (s), -5.0 (q), -5.4 (q); HRMS (ESI) : Calcd for $\mathrm{C}_{12} \mathrm{H}_{23} \mathrm{O}_{3} \mathrm{INaSi}[\mathrm{M}+\mathrm{Na}]^{+}$: 393.0353; Found: 393.0360 .

\section{(-)-Methyl (E)-(S)-3-(tert-butyldimethylsilanyloxy)-5-iodo-4-methylpent-4-enoate (15):}<smiles>[R5]O[C@@H](CC(=O)OC)/C(C)=C/I</smiles>

To a stirred solution of the previously obtained carboxylic acid $(578 \mathrm{mg}, 1.56 \mathrm{mmol}$, 1.0 equiv) in a benzene/ $\mathrm{MeOH}$ mixture $(1 / 1,40 \mathrm{~mL})$ was added trimethylsilyldiazomethane (2.0 mL, 2M in $\mathrm{Et}_{2} \mathrm{O}, 4.05 \mathrm{mmol}, 2.6$ equiv) dropwise until a persistent yellow color was observed. After stirring for $15 \mathrm{~min}$ at $\mathrm{rt}$, the reaction mixture was concentrated in vacuo. Purification of the residue by flash chromatography on a short plug of silica gel (Petroleum ether/EtOAc: 95/5) provided the desired methyl ester 15 (597 mg, quantitative) as a colorless oil.

$\boldsymbol{R} \boldsymbol{f} \approx 0.8$ (Petroleum ether/EtOAc 90:10); $[\boldsymbol{\alpha}]^{\mathbf{2 0}} \mathbf{D}-27.9$ (c 0.565, $\left.\mathrm{CHCl}_{3}\right) ;$ IR (film) : 2952, 2927, 2856, 1740, 1436, 1286, 1251, 1084, 949, 830, 777, $676 \mathrm{~cm}^{-1} ;{ }^{1} \mathbf{H}$ NMR (CDCl $): \delta=$ 6.30 (quint $\left._{\text {app }}, 1 \mathrm{H}, J=1.0 \mathrm{~Hz}\right), 4.65(\mathrm{ddd}, 1 \mathrm{H}, J=9.0,4.2 \mathrm{~Hz}, 1.0 \mathrm{~Hz}), 3.66(\mathrm{~s}, 3 \mathrm{H}), 2.55$ (dd, $1 \mathrm{H}, J=14.4,9.0 \mathrm{~Hz}), 2.41(\mathrm{dd}, 1 \mathrm{H}, J=14.4,4.2 \mathrm{~Hz}), 1.79$ (d, 3H, $J=1.0 \mathrm{~Hz}), 0.84(\mathrm{~s}, 9 \mathrm{H})$, 0.03 (s, 3H), -0.02 (s, 3H); ${ }^{13} \mathbf{C}$ NMR (CDCl $): \delta=171.1$ (s), 149.1 (s), 78.8 (d), 74.3 (d), 51.7 (q), 42.1 (t), 25.6 (3q), 19.3 (q), 18.0 (s), -5.0 (q), -5.5 (q); MS (EI, $70 \mathrm{eV}): \mathrm{m} / \mathrm{z}$ (\%): 369 (1), 327 (100), 311 (3), 285 (10), 253 (6), 185 (10), 131 (25), 89 (62), 75 (11), 73 (15), 59 (9); HRMS (ESI) : Calcd for $\mathrm{C}_{13} \mathrm{H}_{25} \mathrm{O}_{3} \mathrm{INaSi}[\mathrm{M}+\mathrm{Na}]^{+}$: 407.0510 ; Found: 407.0517. 
(+)-Methyl (4E,6E)-(S)-3-(tert-butyldimethylsilanyloxy)-4-methyltetradeca-4,6-dienoate (16):

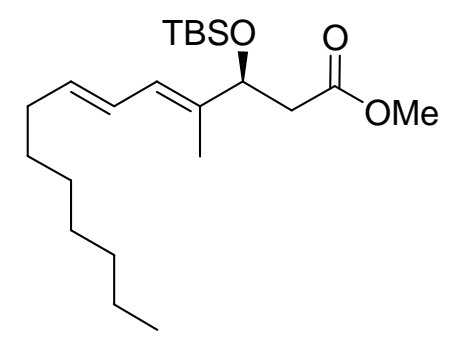

To a stirred solution of vinyl iodide 15 (458 mg, $1.19 \mathrm{mmol}, 1.0$ equiv) and vinyl stannane 11 (993 mg, 2.39 mmol, 2.0 equiv) in anhydrous and degassed DMF (15 mL) was added $\mathrm{PdCl}_{2}(\mathrm{MeCN})_{2}(15 \mathrm{mg}, 0.06 \mathrm{mmol}, 0.05$ equiv) at $\mathrm{rt}$ under an argon atmosphere. After $12 \mathrm{~h}$ of stirring at $\mathrm{rt}$, the resulting dark reaction mixture was diluted in $\mathrm{Et}_{2} \mathrm{O}(25 \mathrm{~mL})$ and poured into a saturated aqueous $\mathrm{NH}_{4} \mathrm{Cl}$ solution $(10 \mathrm{~mL})$. The aqueous layer was extracted with $\mathrm{Et}_{2} \mathrm{O}(3 \times 25 \mathrm{~mL})$ and the combined organic layers were washed with brine $(15 \mathrm{~mL})$, dried over $\mathrm{MgSO}_{4}$, filtered and concentrated in vacuo. Purification of the residue by flash chromatography on silica gel (Petroleum ether/EtOAc : 99/1) provided the desired $(E, E)$ diene $16(38 \mathrm{mg}, 79 \%)$ as a yellow oil.

$\boldsymbol{R} \boldsymbol{f} \approx 0.9$ (Petroleum ether/EtOAc 95:5); $[\boldsymbol{\alpha}]^{\mathbf{2 0}}{ }_{\mathbf{D}}+3.2$ (c 0.22, $\mathrm{CHCl}_{3}$ ); IR (film): 2927, 2856,

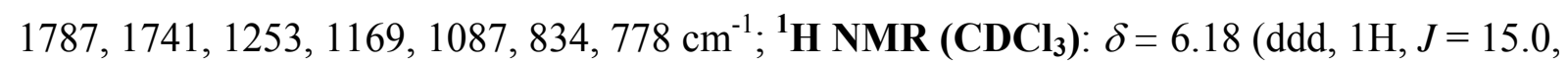
10.8, 1.3 Hz), 5.97 (br d, 1H, $J=10.8 \mathrm{~Hz}), 5.66$ (dt, 1H, $J=15.0,6.8 \mathrm{~Hz}), 4.50$ (dd, 1H, $J=$ 9.3, $4.0 \mathrm{~Hz}$ ), 3.65 (s, 3H), 2.56 (ddd, $1 \mathrm{H}, J=14.1,9.3,1.1 \mathrm{~Hz}), 2.38$ (br dd, 1H, $J=14.1,4.0$ Hz), 2.09 (qapp, 2H, J=7.1 Hz), 1.69 (s, 3H), 1.38 (m, 2H), 1.31-1.00 (m, 8H), 0.87 (m, 3H),

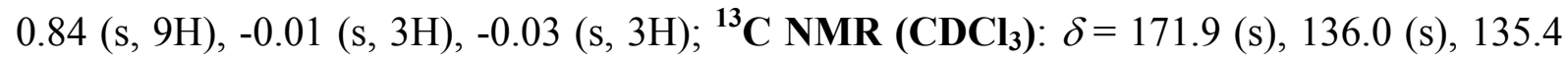
(d), 125.9 (d), 125.7 (d), 75.3 (d), 51.5 (q), $42.4(\mathrm{t}), 33.0(\mathrm{t}), 31.8$ (t), $29.4(\mathrm{t}), 29.2(2 \mathrm{t}), 25.7$ $(3 q), 22.7$ (t), 18.1 (s), 14.1 (q), 11.6 (q), -4.8 (q), -5.4 (q); HRMS (ESI) : Calcd for $\mathrm{C}_{22} \mathrm{H}_{42} \mathrm{O}_{3} \mathrm{SiNa}[\mathrm{M}+\mathrm{Na}]^{+}$: 405.2795; Found: 405.2802. 


\section{(-)-Methyl (4E,6E)-(S)-3-hydroxy-4-methyltetradeca-4,6-dienoate:}

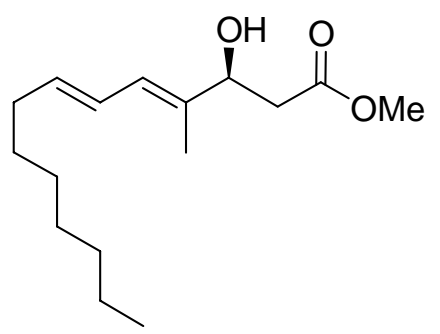

To a stirred solution of silyl ether 16 (340 mg, $0.92 \mathrm{mmol}, 1.0$ equiv) in THF (25 mL) was added tetra- $n$-butylammonium fluoride (1.2 mL, $1 \mathrm{M}$ in THF, $1.20 \mathrm{mmol}, 1.3$ equiv) dropwise. After stirring the resulting brownish solution for $5 \mathrm{~h}$, the reaction was quenched by addition of a saturated aqueous solution of $\mathrm{NH}_{4} \mathrm{Cl}(20 \mathrm{~mL})$. The aqueous layer was extracted with $\mathrm{Et}_{2} \mathrm{O}(3 \times 20 \mathrm{~mL})$ and the combined organic layers were washed with brine $(20 \mathrm{~mL})$, dried over $\mathrm{MgSO}_{4}$, filtered and concentrated in vacuo. Purification of the residue by flash chromatography on silica gel (Petroleum ether/EtOAc : 90/10) provided the desired $\beta$-hydroxy ester (219 mg, 89\%) as a yellow oil.

$\boldsymbol{R f} \approx 0.2$ (Petroleum ether/EtOAc 90:10); $[\boldsymbol{\alpha}]^{\mathbf{2 0}}{ }_{\mathbf{D}}-1.5$ (c 1.02, $\left.\mathrm{CHCl}_{3}\right) ; \mathbf{I R}$ (film) : 3443, 2954, 2922, 2853, 1723, 1437, 1163, 963, $888 \mathrm{~cm}^{-1} ;{ }^{\mathbf{1}} \mathbf{H} \mathbf{N M R}\left(\mathbf{C D C l}_{\mathbf{3}}\right): \delta=6.22(\mathrm{ddt}, 1 \mathrm{H}, J=14.9$, 10.8, 1.4 Hz), 6.07 (br d, 1H, $J=11.0 \mathrm{~Hz}), 5.71$ (dt, 1H, $J=14.9,7.0 \mathrm{~Hz}), 4.48$ (dd, 1H, $J=$ 8.5, 4.2 Hz), 3.71 (s, 3H), 2.69 (br s, 1H, OH), 2.62-2.50 (m, 2H), 2.09 (qapp, 2H, J=7.0 Hz), $1.75(\mathrm{~d}, 3 \mathrm{H}, J=1.0 \mathrm{~Hz}), 1.38(\mathrm{~m}, 2 \mathrm{H}), 1.32-1.24(\mathrm{~m}, 8 \mathrm{H}), 0.88(\mathrm{t}, 3 \mathrm{H}, J=7.0 \mathrm{~Hz}) ;{ }^{13} \mathbf{C} \mathbf{~ N M R}$ $\left(\mathbf{C D C l}_{3}\right): \delta=173.0$ (s), 136.1 (d), 134.8 (s), 125.9 (d), 125.6 (d), 73.2 (d), 51.9 (q), 40.0 (t), $33.0(\mathrm{t}), 31.8(\mathrm{t}), 29.4(\mathrm{t}), 29.2(2 \mathrm{t}), 22.7(\mathrm{t}), 14.1(\mathrm{q}), 12.5(\mathrm{q})$; HRMS (ESI) : Calcd for $\mathrm{C}_{16} \mathrm{H}_{28} \mathrm{O}_{3} \mathrm{Na}[\mathrm{M}+\mathrm{Na}]^{+}: 291.1931$; Found: 291.1934. 


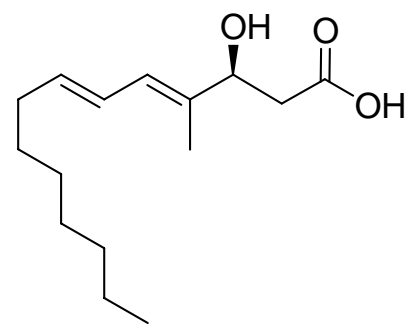

To a stirred solution of the previously obtained methyl ester (108 mg, $0.403 \mu \mathrm{mol}, 1.0$ equiv) in a THF/MeOH/ $\mathrm{H}_{2} \mathrm{O}$ mixture $(2 / 2 / 1,25 \mathrm{~mL})$ was added solid $\mathrm{LiOH}(193 \mathrm{mg}, 8.1$ mmol, 20 equiv) in one portion at $0{ }^{\circ} \mathrm{C}$. The resulting yellow mixture was allowed to reach $\mathrm{rt}$ and stirring was carried on for $2 \mathrm{~h}$. The mixture was then concentrated under reduced pressure to remove THF and $\mathrm{MeOH}$, diluted with EtOAc $(25 \mathrm{~mL})$ and acidified with a saturated aqueous solution of $\mathrm{NaH}_{2} \mathrm{PO}_{4}(\mathrm{pH}=4.5,15 \mathrm{~mL})$. The layers were separated and the aqueous phase was extracted with EtOAc $(3 \times 20 \mathrm{~mL})$, dried over $\mathrm{MgSO}_{4}$, filtered and concentrated in vacuo to provide the corresponding crude carboxylic acid S-17 (102 mg, 100\%) which was used in the next step without further purification.

\section{IV- $\quad$ Synthesis of carboxylic acid $R-17$}

(+)-tert-Butyl (E)-(R)-3-hydroxy-5-iodo-4-methylpent-4-enoate (18):

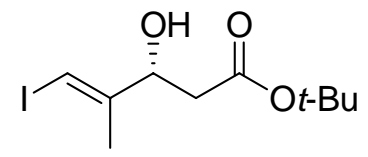

To a solution of $\mathrm{CpTiCl}_{3}\left(2.56 \mathrm{~g}, 11.67 \mathrm{mmol}, 1.0\right.$ equiv) in anhydrous $\mathrm{Et}_{2} \mathrm{O}(80 \mathrm{~mL})$ was added in one portion solid diacetone-D-glucose $(6.1 \mathrm{~g}, 23.34 \mathrm{mmol}, 2.0$ equiv) at rt. After stirring for $5 \mathrm{~min}$, freshly distilled $\mathrm{Et}_{3} \mathrm{~N}(4.64 \mathrm{~mL}, 33.4 \mathrm{mmol}, 2.85$ equiv) dissolved in anhydrous $\mathrm{Et}_{2} \mathrm{O}(40 \mathrm{~mL})$ was added via cannula to the previous solution. The resulting thick slurry was stirred at $\mathrm{rt}$ for $15 \mathrm{~h}$, and the triethylamine salts were removed by filtration under an argon atmosphere. The yellow $0.095 \mathrm{M}$ stock solution in $\mathrm{Et}_{2} \mathrm{O}$ of chloro(cyclopentadienyl)- 
bis(1,2:5,6-di- $O$-isopropylidene- $\alpha$-D-glucofuranos-3-O-yl)titanate thus obtained was kept for the next reaction under an argon atmosphere in the fridge at $0{ }^{\circ} \mathrm{C}$.

To a solution of LDA (2.99 mL, $1 \mathrm{M}$ in THF- $n$-hexanes, $2.99 \mathrm{mmol}, 1.5$ equiv) in anhydrous $\mathrm{Et}_{2} \mathrm{O}(40 \mathrm{~mL})$, was added a solution of tert-BuOAc $(403 \mu \mathrm{L}, 2.99 \mathrm{mmol}, 1.5$ equiv) in $\mathrm{Et}_{2} \mathrm{O}(5 \mathrm{~mL})$ dropwise at $-78^{\circ} \mathrm{C}$. After stirring for $30 \mathrm{~min}$, a solution of the titanium reagent described above (42 mL, $0.095 \mathrm{M}$ in $\mathrm{Et}_{2} \mathrm{O}, 3.98 \mathrm{mmol}, 2$ equiv) was subsequently added via cannula dropwise over $20 \mathrm{~min}$, and stirring was carried on for further $30 \mathrm{~min}$. The temperature was then slowly raised to $-30{ }^{\circ} \mathrm{C}$, and after stirring at this temperature for $45 \mathrm{~min}$ the solution was finally recooled to $-78{ }^{\circ} \mathrm{C}$. The previously obtained crude (E)-3-iodo-2methylacrylaldehyde 13 (390 mg, 1.99 mmol, 1.0 equiv) was azeotroped three times with toluene, then dissolved in anhydrous $\mathrm{Et}_{2} \mathrm{O}(15 \mathrm{~mL})$ and subsequently added dropwise within $10 \mathrm{~min}$ to the previous solution. After stirring at $-78{ }^{\circ} \mathrm{C}$ for $1 \mathrm{~h}$, the reaction was quenched by addition of a $\mathrm{THF} / \mathrm{H}_{2} \mathrm{O}$ solution $(1 / 1,60 \mathrm{~mL})$ and the mixture was stirred for $1 \mathrm{~h}$. The resulting white slurry was filtered through a short pad of Celite ${ }^{\circledR}$ in order to remove the solid titanium salts, and the filtrate was washed with brine $(80 \mathrm{~mL})$. The aqueous layers were extracted with $\mathrm{Et}_{2} \mathrm{O}(3 \times 80 \mathrm{~mL})$ and the combined organic phases where dried over $\mathrm{MgSO}_{4}$, filtered and evaporated to dryness under reduced pressure. The resulting crude residue was purified by flash chromatography on silica gel (Petroleum ether/EtOAc : 95/5) to yield compound 18 (441 mg, 71\%) as a colorless oil.

$\boldsymbol{R} \boldsymbol{f} \approx 0.25$ (Petroleum ether/EtOAc 95:5); $[\boldsymbol{\alpha}]^{\mathbf{2 0}}{ }_{\mathbf{D}}+15.5$ (c 1.11, $\mathrm{CHCl}_{3}$ ); IR (film): 3401, 2977, 2917, 1704, 1367, 1248, 1149, 1038, 1018, 954, $840 \mathrm{~cm}^{-1} ;{ }^{1} \mathbf{H}$ NMR (CDCl $\left.\mathbf{3}\right): \delta=6.39$ (quint $\left._{\text {app }}, 1 \mathrm{H}, J=1.1 \mathrm{~Hz}\right), 4.52(\mathrm{~m}, 1 \mathrm{H}), 3.24(\mathrm{br} \mathrm{d}, 1 \mathrm{H}, J=3.7 \mathrm{~Hz}, \mathrm{OH}), 2.54-2.43(\mathrm{~m}, 2 \mathrm{H})$, $1.83(\mathrm{~d}, 3 \mathrm{H}, J=1.1 \mathrm{~Hz}), 1.46(\mathrm{~s}, 9 \mathrm{H}) ;{ }^{13} \mathbf{C} \mathbf{N M R}\left(\mathbf{C D C l}_{3}\right): \delta=171.4(\mathrm{~s}), 147.7$ (s), $81.8(\mathrm{~d})$, $79.1(\mathrm{~s}), 72.5(\mathrm{~d}), 40.8(\mathrm{t}), 28.1(3 \mathrm{q}), 20.5(\mathrm{q})$. 


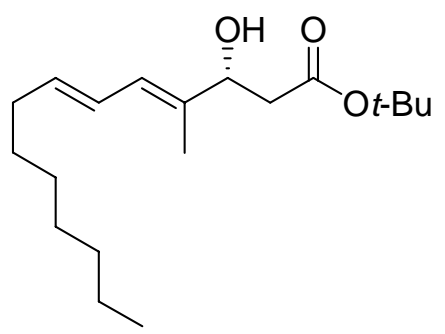

To a stirred solution of vinyl iodide 18 (305 $\mathrm{mg}, 0.98 \mu \mathrm{mol}, 1.0$ equiv) and vinyl stannane 11 (811 mg, $1.95 \mathrm{mmol}, 2.0$ equiv) in anhydrous and degassed DMF (10 mL) was added $\mathrm{PdCl}_{2}(\mathrm{MeCN})_{2}(13 \mathrm{mg}, 0.049 \mathrm{mmol}, 0.05$ equiv $)$ at $\mathrm{rt}$. After $12 \mathrm{~h}$ of stirring at $\mathrm{rt}$, the resulting dark reaction mixture was diluted with $\mathrm{Et}_{2} \mathrm{O}(20 \mathrm{~mL})$ and poured into a saturated aqueous $\mathrm{NH}_{4} \mathrm{Cl}$ solution $(15 \mathrm{~mL})$. The aqueous layer was extracted with $\mathrm{Et}_{2} \mathrm{O}(3 \times 20 \mathrm{~mL})$ and the combined organic layers were washed with brine $(10 \mathrm{~mL})$, dried over $\mathrm{MgSO}_{4}$, filtered and concentrated in vacuo. Purification of the residue by flash chromatography on silica gel (Petroleum ether/EtOAc : 95/5 to 90/10) provided the desired (E,E)-diene 19 (161 mg, 53\%) as a yellow oil.

$\boldsymbol{R} \boldsymbol{f} \approx 0.5$ (Petroleum ether/EtOAc 90:10); $[\boldsymbol{\alpha}]^{\mathbf{2 0}}{ }_{\mathbf{D}}+1.2$ (c 0.95, $\mathrm{CHCl}_{3}$ ); IR (film): 3420, 2923, 2855, 1719, 1457, 1368, 1250, 1150, 1063, 841, $737 \mathrm{~cm}^{-1} ;{ }^{\mathbf{1}} \mathbf{H} \mathbf{N M R}\left(\mathbf{C D C l}_{3}\right): \delta=6.21(\mathrm{br}$ dd, $1 \mathrm{H}, J=15.0,10.8 \mathrm{~Hz}), 6.05(\mathrm{~d}, 1 \mathrm{H}, J=10.8 \mathrm{~Hz}), 5.69$ (dt, $1 \mathrm{H}, J=14.9,7.0 \mathrm{~Hz}), 4.41$ (br dd, $1 \mathrm{H}, J=7.8,4.6 \mathrm{~Hz}$ ), 2.95 (br s, 1H, OH), 2.52-2.41 (m, 2H), 2.09 (qapp, 2H, J=7.2 Hz), $1.73(\mathrm{~s}, 3 \mathrm{H}), 1.45(\mathrm{~s}, 9 \mathrm{H}), 1.37(\mathrm{~m}, 2 \mathrm{H}), 1.32-1.24(\mathrm{~m}, 8 \mathrm{H}), 0.87(\mathrm{t}, 3 \mathrm{H}, J=6.2 \mathrm{~Hz}) ;{ }^{13} \mathbf{C}$ NMR (CDCl $): \delta=172.0$ (s), 135.8 (d), 135.0 (s), 125.8 (d), 125.7 (d), 81.3 (s), 73.3 (d), 41.1 $(\mathrm{t}), 33.0(\mathrm{t}), 31.8(\mathrm{t}), 29.4(\mathrm{t}), 29.2(2 \mathrm{t}), 28.1(3 \mathrm{t}), 22.7(\mathrm{t}), 14.1(\mathrm{q}), 12.5(\mathrm{q})$; HRMS (ESI): Calcd for $\mathrm{C}_{19} \mathrm{H}_{34} \mathrm{O}_{3} \mathrm{Na}[\mathrm{M}+\mathrm{Na}]^{+}$: 333.2400; Found: 333.2405. 


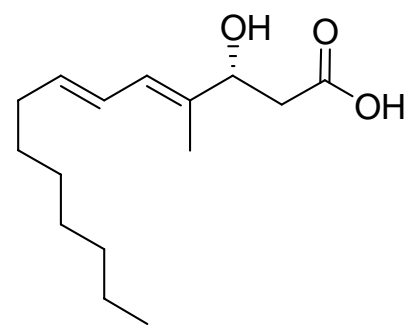

To a stirred solution of tert-butyl ester 19 (89 $\mathrm{mg}, 0.287 \mathrm{mmol}, 1.0$ equiv) in a $\mathrm{MeOH} / \mathrm{H}_{2} \mathrm{O}$ mixture (2/1, $6 \mathrm{~mL}$ ) was added solid $\mathrm{NaOH}(57 \mathrm{mg}, 1.72 \mathrm{mmol}, 5$ equiv) in one portion at rt. The resulting mixture was heated to $70{ }^{\circ} \mathrm{C}$, and stirring was carried on for $2 \mathrm{~h}$. The mixture was allowed to cool to $\mathrm{rt}$, and then concentrated under reduced pressure to remove $\mathrm{MeOH}$. EtOAc $(15 \mathrm{~mL})$ was added and the resulting solution was acidified with a saturated aqueous solution of $\mathrm{NaH}_{2} \mathrm{PO}_{4}(\mathrm{pH}=4.5,10 \mathrm{~mL})$. The layers were separated and the aqueous phase was extracted with EtOAc $(3 \times 10 \mathrm{~mL})$. The combined organic layers were washed with brine $(10 \mathrm{~mL})$, dried over $\mathrm{MgSO}_{4}$, filtered and concentrated in vacuo to provide the corresponding crude carboxylic acid $R-17(72 \mathrm{mg}, 99 \%)$ as a viscous yellow oil which was used in the next step without further purification. 
(+)-Methyl $(2 E, 4 E, 6 E)-9-\{(2 S, 3 R)-4-[(4 E, 6 E)-(S)-3-h y d r o x y-4-m e t h y l t e t r a d e c a-4,6-$ dienoylamino]2-methyl-3-(triisopropylsilanyloxy)butyrylamino\}nona-2,4,6-trienoate $(S$ 20):

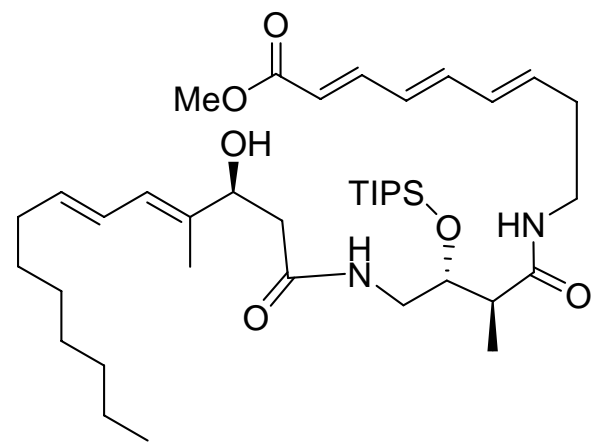

To a solution of free amine 8 previously obtained (136 mg, $0.300 \mathrm{mmol}, 1.0$ equiv) and carboxylic acid $S-17$ (76 mg, 0.300 mmol, 1.0 equiv) in anhydrous $\mathrm{CH}_{3} \mathrm{CN}(15 \mathrm{~mL})$, at $0{ }^{\circ} \mathrm{C}$, were successively added 1-hydroxybenzotriazole ( $45 \mathrm{mg}, 0.330 \mathrm{mmol}, 1.1$ equiv), $\mathrm{O}$ (1H-benzotriazole-1-yl)- $N, N, N^{\prime}, N^{\prime}$-tetramethyluronium hexafluorophosphate (125 mg, 0.330 mmol, 1.1 equiv) and $N$-methylmorpholine (109 $\mu \mathrm{L}, 0.990 \mathrm{mmol}, 3.0$ equiv). The solution was allowed to warm to $\mathrm{rt}$ and after stirring for $6 \mathrm{~h}$, the resulting brown mixture was hydrolyzed by addition of water $(5 \mathrm{~mL}) . \mathrm{CH}_{3} \mathrm{CN}$ was removed under reduced pressure and the resulting aqueous layer was extracted with EtOAc $(3 \times 15 \mathrm{~mL})$. The combined organic layers were successively washed with a saturated aqueous solution of $\mathrm{NaHCO}_{3}(15 \mathrm{~mL})$, a saturated aqueous solution of $\mathrm{NH}_{4} \mathrm{Cl}(15 \mathrm{~mL})$ and brine $(15 \mathrm{~mL})$. The organic layer was dried over $\mathrm{MgSO}_{4}$, filtered and evaporated to dryness under reduced pressure. The residue thus obtained was purified by flash chromatography on silica gel (Petroleum ether/EtOAc 80:20 to 50:50) which provided the desired diamide $S-\mathbf{2 0}$ (156 mg, 76\% over 2 steps) as a colorless oil.

$\boldsymbol{R f} \approx 0.3\left(\mathrm{CH}_{2} \mathrm{Cl}_{2} / \mathrm{MeOH} 95: 5\right) ;[\boldsymbol{\alpha}]^{\mathbf{2 0}}{ }_{\mathbf{D}}+11.9\left(\right.$ c 0.72, $\left.\mathrm{CHCl}_{3}\right) ; \mathbf{I R}$ (film) : 3305, 2922, 2854, $1717,1693,1619,1541,1461,1435,1385,1272,1205,1180,1135,1006,844,723,681$ $\mathrm{cm}^{-1} ;{ }^{1} \mathbf{H}$ NMR $\left(\mathbf{C D C l}_{3}\right): \delta=7.28(\mathrm{dd}, 1 \mathrm{H}, J=15.2,11.2 \mathrm{~Hz}), 6.66(\mathrm{~m}, 1 \mathrm{H}, \mathrm{NH}), 6.49(\mathrm{dd}$, $1 \mathrm{H}, J=14.8,10.7 \mathrm{~Hz}), 6.39(\mathrm{~m}, 1 \mathrm{H}, \mathrm{NH}), 6.27-6.14(\mathrm{~m}, 3 \mathrm{H}), 6.06(\mathrm{~d}, 1 \mathrm{H}, J=11.0 \mathrm{~Hz}), 5.86$ (d, 1H, $J=15.2 \mathrm{~Hz}), 5.84(\mathrm{~m}, 1 \mathrm{H}), 5.69$ (dt, 1H, $J=14.9,7.0 \mathrm{~Hz}), 4.38$ (br d, 1H, $J=6.5 \mathrm{~Hz}$ ), 4.07 (quint $\left._{\text {app }}, 1 \mathrm{H}, J=4.1 \mathrm{~Hz}\right), 3.80(\mathrm{~m}, 1 \mathrm{H}, \mathrm{OH}), 3.74(\mathrm{~s}, 3 \mathrm{H}), 3.66(\mathrm{~m}, 1 \mathrm{H}), 3.34(\mathrm{~m}, 2 \mathrm{H})$, 
$2.87(\mathrm{~m}, 1 \mathrm{H}), 2.49(\mathrm{~m}, 1 \mathrm{H}), 2.41-2.31(\mathrm{~m}, 4 \mathrm{H}), 2.08$ (qapp, 2H, J = $7.0 \mathrm{~Hz}), 1.72(\mathrm{~s}, 3 \mathrm{H}), 1.37$ (m, 2H), 1.32-1.22 (m, 8H), 1.19 (d, 3H, $J=7.2 \mathrm{~Hz}), 1.14-1.05(\mathrm{~m}, 21 \mathrm{H}), 0.87$ (t, 3H, $J=6.9$ $\mathrm{Hz}) ;{ }^{13} \mathbf{C}$ NMR (CDCl$): \delta=174.7$ (s), 172.3 (s), 167.5 (s), 144.6 (d), 140.2 (d), 135.9 (d), 135.8 (d), 135.4 (s), 132.0 (d), 128.9 (d), 125.7 (d), 125.4 (d), 120.4 (d), 73.5 (d), 72.0 (d), $51.5(\mathrm{q}), 44.9(\mathrm{~d}), 43.0(\mathrm{t}), 41.3(\mathrm{t}), 38.4(\mathrm{t}), 33.1(\mathrm{t}), 33.0(\mathrm{t}), 31.8(\mathrm{t}), 29.4(\mathrm{t}), 29.2(2 \mathrm{t}), 22.7$ (t), 18.2 (6q), 14.9 (q), 14.1 (q), 12.8 (q), 12.7 (3d); HRMS (ESI) : Calcd for $\mathrm{C}_{39} \mathrm{H}_{68} \mathrm{O}_{6} \mathrm{~N}_{2} \mathrm{NaSi}[\mathrm{M}+\mathrm{Na}]^{+}:$711.4739; Found: 711.4735.

(+)-Methyl $(2 E, 4 E, 6 E)-9-\{(2 S, 3 R)-4-[(4 E, 6 E)-(R)-3-h y d r o x y-4-m e t h y l t e t r a d e c a-4,6-$ dienoylamino]2-methyl-3-(triisopropylsilanyloxy)butyrylamino nona-2,4,6-trienoate (R-20):

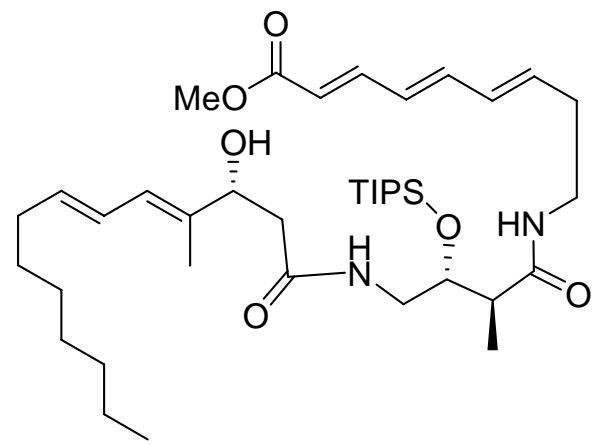

$\boldsymbol{R f} \approx 0.3\left(\mathrm{CH}_{2} \mathrm{Cl}_{2} / \mathrm{MeOH} 95: 5\right) ;[\boldsymbol{\alpha}]^{\mathbf{2 0}}{ }_{\mathbf{D}}+15.8$ (c 0.165, $\left.\mathrm{CHCl}_{3}\right) ; \mathbf{I R}$ (film) : 3307, 2922, 2854, 1717, 1647, 1618, 1536, 1461, 1434, 1234, 1137, 1005, 843, $680 \mathrm{~cm}^{-1} ;{ }^{\mathbf{1}} \mathbf{H}$ NMR (CDCl $\left.\mathbf{3}\right)$ : $\delta=7.29(\mathrm{dd}, 1 \mathrm{H}, J=15.3,11.2 \mathrm{~Hz}), 6.53(\mathrm{~m}, 1 \mathrm{H}, \mathrm{NH}), 6.50(\mathrm{dd}, 1 \mathrm{H}, J=15.0,10.8 \mathrm{~Hz}), 6.31$ (m, 1H, NH), 6.28-6.15 (m, 3H), $6.06(\mathrm{~d}, 1 \mathrm{H}, J=10.6 \mathrm{~Hz}), 5.87(\mathrm{~d}, 1 \mathrm{H}, J=15.3 \mathrm{~Hz}), 5.83$ $(\mathrm{m}, 1 \mathrm{H}), 5.70(\mathrm{dt}, 1 \mathrm{H}, J=14.8,7.0 \mathrm{~Hz}), 4.42(\mathrm{br} \mathrm{dd}, 1 \mathrm{H}, J=8.2,3.4 \mathrm{~Hz}), 4.07$ (quint $_{\text {app }}, 1 \mathrm{H}, J$ $=4.1 \mathrm{~Hz}), 3.79(\mathrm{~m}, 1 \mathrm{H}), 3.74(\mathrm{~s}, 3 \mathrm{H}), 3.46(\mathrm{~m}, 1 \mathrm{H}, \mathrm{OH}), 3.35$ (quint, $2 \mathrm{H}, J=6.2 \mathrm{~Hz}), 2.95$ (ddd, $1 \mathrm{H}, J=13.6,8.7,4.8 \mathrm{~Hz}), 2.51(\mathrm{~m}, 1 \mathrm{H}), 2.42-2.32(\mathrm{~m}, 4 \mathrm{H}), 2.09$ (qapp, $2 \mathrm{H}, J=7.2 \mathrm{~Hz})$, $1.73(\mathrm{~s}, 3 \mathrm{H}), 1.37(\mathrm{~m}, 2 \mathrm{H}), 1.33-1.23(\mathrm{~m}, 8 \mathrm{H}), 1.21$ (d, 3H, J = 7.2 Hz), 1.12-1.05 (m, 21H), 0.88 (t, 3H, $J=7.0 \mathrm{~Hz}) ;{ }^{13} \mathbf{C}$ NMR $\left(\mathbf{C D C l}_{3}\right): \delta=174.5$ (s), 172.1 (s), 167.5 (s), 144.6 (d), 140.3 (d), 135.9 (d), 135.8 (d), 135.4 (s), 132.1 (d), 128.9 (d), 125.7 (d), 125.6 (d), 120.4 (d), $73.6(\mathrm{~d}), 72.1(\mathrm{~d}), 51.6(\mathrm{q}), 45.0(\mathrm{~d}), 42.9(\mathrm{t}), 41.6(\mathrm{t}), 38.5(\mathrm{t}), 33.1(\mathrm{t}), 33.0(\mathrm{t}), 31.8(\mathrm{t}), 29.4$ (t), 29.2 (2t), 22.7 (t), 18.2 (6q), 14.7 (q), 14.1 (q), 12.7 (q), 12.6 (3d); HRMS (ESI): Calcd for $\mathrm{C}_{39} \mathrm{H}_{68} \mathrm{O}_{6} \mathrm{~N}_{2} \mathrm{NaSi}[\mathrm{M}+\mathrm{Na}]^{+}$: 711.4739; Found: 711.4733 . 


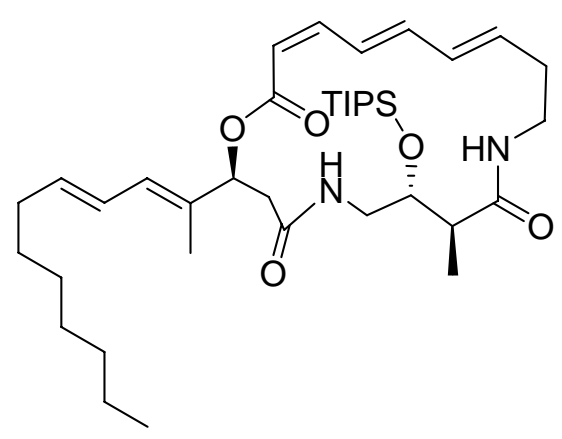

To a stirred solution of trienic ester $S-20$ (116 $\mathrm{mg}, 0.168 \mathrm{mmol}, 1.0$ equiv) in a THF/MeOH/ $\mathrm{H}_{2} \mathrm{O}$ mixture $(2 / 2 / 1,25 \mathrm{~mL})$ was added solid $\mathrm{LiOH}(81 \mathrm{mg}, 3.37 \mathrm{mmol}, 20$ equiv) in one portion at $0{ }^{\circ} \mathrm{C}$. The resulting yellow mixture was allowed to reach $\mathrm{rt}$, and stirring was carried on for $12 \mathrm{~h}$. The mixture was then concentrated under reduced pressure to remove THF and $\mathrm{MeOH}$, diluted with EtOAc $(30 \mathrm{~mL})$, and acidified with a saturated aqueous solution of $\mathrm{NaH}_{2} \mathrm{PO}_{4}(\mathrm{pH}=4.5,15 \mathrm{~mL})$. The layers were separated, and the aqueous phase was extracted with EtOAc ( $3 \times 15 \mathrm{~mL})$. The combined organic layers were washed with brine $(15 \mathrm{~mL})$, dried over $\mathrm{MgSO}_{4}$, filtered and concentrated in vacuo to provide the corresponding crude carboxylic acid S-21.

To a solution of the previously obtained crude seco-acid in dry THF (15 mL) were successively added $\mathrm{Et}_{3} \mathrm{~N}$ (187 $\mu \mathrm{L}, 1.344$ mmol, 8.0 equiv) followed by 2,4,6-trichlorobenzoyl chloride ( $63 \mu \mathrm{L}, 0.403 \mathrm{mmol}, 2.4$ equiv) dropwise. The mixture was allowed to warm to $\mathrm{rt}$ and stirred for $3 \mathrm{~h}$. The resulting heterogeneous cloudy mixture was filtered over a cotton pad to remove the ammonium salts, and concentrated under reduced pressure. The obtained mixed anhydride residue was then dissolved in a THF/toluene mixture $(1 / 9,10 \mathrm{~mL})$ and was slowly added over a period of $4 \mathrm{~h}$ via a syringe pump to a solution of 4-dimethylaminopyridine (123 $\mathrm{mg}, 1.01 \mathrm{mmol}, 6$ equiv) in dry toluene $(60 \mathrm{~mL})$ at $65^{\circ} \mathrm{C}$. The mixture was stirred at this temperature for an additional $2 \mathrm{~h}$, then allowed to cool to $\mathrm{rt}$ and hydrolyzed by adding a saturated aqueous solution of $\mathrm{NaH}_{2} \mathrm{PO}_{4}(\mathrm{pH}=4.5,20 \mathrm{~mL})$. The layers were separated and the aqueous phase was extracted with EtOAc $(3 \times 30 \mathrm{~mL})$. The combined organic layers were washed with brine $(30 \mathrm{~mL})$, dried over $\mathrm{MgSO}_{4}$, filtered and evaporated in vacuo. The residue was purified by flash chromatography on silica gel (Petroleum ether/EtOAc 90:10 to 70:30) 
which provided the $(2 Z, 4 E, 6 E)$ protected macrolactone $S-22(53 \mathrm{mg}, 48 \%$ over 2 steps) as a yellow foam, contaminated by traces of non identified impurities.

$\boldsymbol{R} \boldsymbol{f} \approx 0.25$ (Petroleum ether/EtOAc 70:30); $[\boldsymbol{\alpha}]^{\mathbf{2 0}}{ }_{\mathbf{D}}+174.8$ (c 0.155, $\mathrm{CHCl}_{3}$ ); IR (film): 3284, 2924, 2865, 1704, 1646, 1611, 1540, 1461, 1268, 1234, 1090, 1064, 1011, 882, $680 \mathrm{~cm}^{-1}$; ${ }^{1} \mathbf{H}$ NMR (CDCl $): \delta=7.60$ (br d, 1H, NH), 7.24 (br t, $1 \mathrm{H}, J=13.5 \mathrm{~Hz}), 6.51$ (t, 1H, $J=11.7$ Hz), 6.44-6.30 (m, 2H), $6.20(\mathrm{dd}, 1 \mathrm{H}, J=14.8,10.9 \mathrm{~Hz}), 6.09$ (d, 1H, J = 10.9 Hz), 5.88-5.81 $(\mathrm{m}, 1 \mathrm{H}+\mathrm{NH}), 5.75-5.66(\mathrm{~m}, 2 \mathrm{H}), 5.55(\mathrm{~d}, 1 \mathrm{H}, J=11.6 \mathrm{~Hz}), 3.97(\mathrm{~m}, 1 \mathrm{H}), 3.89$ (ddd, $1 \mathrm{H}, J=$ 6.4, 4.7, 1.6 Hz), $3.56(\mathrm{ddd}, 1 \mathrm{H}, J=12.1,7.1,4.8 \mathrm{~Hz}), 3.32-3.16(\mathrm{~m}, 2 \mathrm{H}), 2.58(\mathrm{~m}, 1 \mathrm{H}), 2.52-$ $2.30(\mathrm{~m}, 4 \mathrm{H}), 2.08$ (br q, 2H, $J=7.1 \mathrm{~Hz}), 1.78(\mathrm{~s}, 3 \mathrm{H}), 1.35(\mathrm{~m}, 2 \mathrm{H}), 1.32-1.22(\mathrm{~m}, 8 \mathrm{H}), 1.22$ $(\mathrm{d}, 3 \mathrm{H}, J=7.2 \mathrm{~Hz}), 1.10-0.95(\mathrm{~m}, 21 \mathrm{H}), 0.88(\mathrm{t}, 3 \mathrm{H}, J=7.0 \mathrm{~Hz}) ;{ }^{13} \mathbf{C} \mathbf{N M R}\left(\mathbf{C D C l}_{3}\right): \delta=$ 175.0 (s), 169.0 (s), 165.4 (s), 141.8 (d), 139.5 (d), 136.3 (d), 132.7 (d), 132.0 (d), 131.1 (s), 129.2 (d), 126.6 (d), 125.5 (d), 118.9 (d), 76.1 (d), 71.1 (d), 49.2 (d), $42.3(\mathrm{t}) 41.1$ (t), 35.6 (t), $33.0(\mathrm{t}), 32.0(\mathrm{t}), 31.8(\mathrm{t}), 29.4(\mathrm{t}), 29.2(\mathrm{t}), 29.1(\mathrm{t}), 22.7(\mathrm{t}), 18.1(6 \mathrm{q}), 14.1(\mathrm{q}), 13.2(\mathrm{q}), 12.4$ (3d), 11.7 (q); HRMS (ESI) : Calcd for $\mathrm{C}_{38} \mathrm{H}_{64} \mathrm{O}_{5} \mathrm{~N}_{2} \mathrm{NaSi}[\mathrm{M}+\mathrm{Na}]^{+}$: 679.4477; Found : 679.4475 .

(-)-(13E,15E,17Z)-(2R,7R,8S)-8-Methyl-2-[(1E,3E)-1-methylundeca-1,3-dienyl]-7triisopropysilanyloxy-1-oxa-5,10-diazacyclononadeca-13,15,17-triene-4,9,19-trione (R-22):

Same procedure as for $(S-22)$

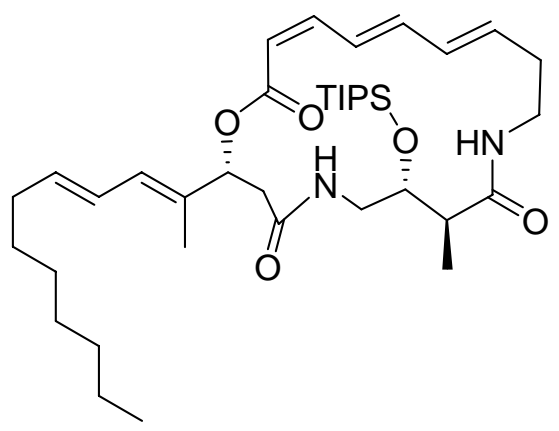

$\boldsymbol{R} \boldsymbol{f} \approx 0.25$ (Petroleum Ether/EtOAc 70:30); $\left[\boldsymbol{\alpha}^{\mathbf{2 0}}{ }_{\mathbf{D}}-382.7\right.$ (c $\left.0.255, \mathrm{CHCl}_{3}\right) ; \mathbf{I R}$ (film) : 3359, $2925,2865,1703,1644,1613,1537,1515,1463,1272,1248,1101,1014,883,826,682$ $\mathrm{cm}^{-1} ;{ }^{1} \mathbf{H}$ NMR $\left(\mathbf{C D C l}_{3}\right) \delta=7.10(\mathrm{br} \mathrm{t}, 1 \mathrm{H}, J=12.9 \mathrm{~Hz}), 6.81(\mathrm{~m}, 1 \mathrm{H}, \mathrm{NH}), 6.52(\mathrm{t}, 1 \mathrm{H}, J=$ $11.7 \mathrm{~Hz}$ ), 6.44-6.35 (m, 2H), 6.20 (dd, 1H, $J=14.8,10.8 \mathrm{~Hz}), 6.09$ (d, 1H, J=10.4 Hz), 5.88- 
$5.80(\mathrm{~m}, 1 \mathrm{H}+\mathrm{NH}), 5.71(\mathrm{dt}, 1 \mathrm{H}, J=14.7,7.0 \mathrm{~Hz}), 5.54(\mathrm{~m}, 1 \mathrm{H}), 5.53(\mathrm{~d}, 1 \mathrm{H}, J=11.9 \mathrm{~Hz})$, $4.12(\mathrm{~m}, 1 \mathrm{H}), 4.02(\mathrm{ddd}, 1 \mathrm{H}, J=9.2,5.8,2.5 \mathrm{~Hz}), 3.92(\mathrm{~m}, 1 \mathrm{H}), 2.97(\mathrm{~m}, 1 \mathrm{H}), 2.84(\mathrm{ddd}, 1 \mathrm{H}$, $J=13.8,9.8,4.1 \mathrm{~Hz}), 2.72-2.45(\mathrm{~m}, 5 \mathrm{H}), 2.29(\mathrm{~m}, 1 \mathrm{H}), 2.08($ br q, $1 \mathrm{H}, J=7.1 \mathrm{~Hz}), 1.77(\mathrm{~s}$, $3 \mathrm{H}), 1.37$ (m, 2H), 1.32-1.20 (m, 8H), 1.14-0.98 (m, 24H), $0.88(\mathrm{t}, 3 \mathrm{H}, J=7.0 \mathrm{~Hz}) .{ }^{13} \mathbf{C}$ NMR $\left(\mathbf{C D C l} \mathbf{3}_{3}\right) \delta=175.3$ (s), 169.5 (s), 165.5 (s), 142.2 (d), 140.1 (d), 136.4 (d), 134.9 (d), 132.0 (d), 131.1 (s), 128.2 (d), 126.9 (d), 125.5 (d), 118.8 (d), 77.1 (d), 72.0 (d), 45.4 (d), 42.8 (t), $41.6(\mathrm{t}), 36.9(\mathrm{t}), 33.0(\mathrm{t}), 31.8(\mathrm{t}), 31.7(\mathrm{t}), 29.3(\mathrm{t}), 29.2(2 \mathrm{t}), 22.7(\mathrm{t}), 18.1(6 \mathrm{q}), 15.3(\mathrm{q}), 14.1$ (q), 12.9 (q), 12.6 (3d); HRMS (ESI) : Calcd for $\mathrm{C}_{38} \mathrm{H}_{64} \mathrm{O}_{5} \mathrm{~N}_{2} \mathrm{NaSi}[\mathrm{M}+\mathrm{Na}]^{+}$: 679.4477; Found: 679.4479.

(+)-(13E,15E,17Z)-(2S,7R,8S)-7-Hydroxy-8-methyl-2-[(1E,3E)-1-methylundéca-1,3dienyl]-1-oxa-5,10-diazacyclononadeca-13,15,17-triene-4,9,19-trione (S-23):

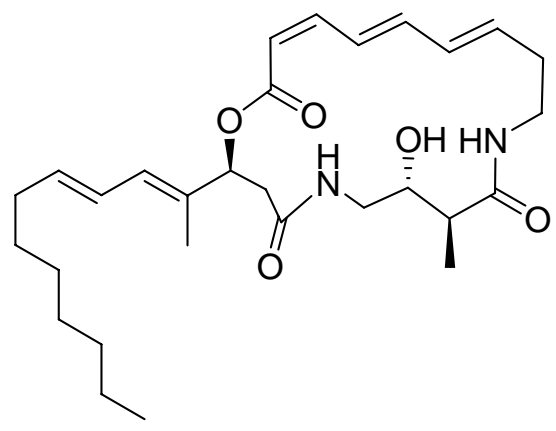

To a stirred solution of protected macrolactone $S-22(9.6 \mathrm{mg}, 0.0146 \mathrm{mmol}, 1.0$ equiv) in dry THF $(2 \mathrm{~mL})$ at $0{ }^{\circ} \mathrm{C}$ was added tetra- $n$-butylammonium fluoride $(1 \mathrm{M}$ in THF, $19 \mu \mathrm{L}$, $0.0189 \mathrm{mmol}, 1.3$ equiv) dropwise. The mixture was allowed to warm to rt, and stirred for $1 \mathrm{~h}$. The resulting brown solution was quenched by adding a saturated aqueous solution of $\mathrm{NH}_{4} \mathrm{Cl}$ $(2 \mathrm{~mL})$, and the aqueous phase was extracted with $\mathrm{Et}_{2} \mathrm{O}(3 \times 5 \mathrm{~mL})$. The combined organic layers were washed with brine $(5 \mathrm{~mL})$, dried over $\mathrm{MgSO}_{4}$, filtered and evaporated under reduced pressure. The residue was purified by preparative TLC $\left(\mathrm{SiO}_{2}, \mathrm{CHCl}_{3} / \mathrm{MeOH}\right.$ 90:10) to afford the $(2 Z, 4 E, 6 E)$ macrolactone $S-\mathbf{2 3}(6.1 \mathrm{mg}, 84 \%)$ as a white solid.

$\boldsymbol{R f} \approx 0.5\left(\mathrm{CHCl}_{3} / \mathrm{MeOH} 90: 10\right) ;[\boldsymbol{\alpha}]^{\mathbf{2 0}}{ }_{\mathbf{D}}+55.9$ (c 0.195, $\left.\mathrm{CHCl}_{3}\right) ; \mathbf{I R}$ (film): 3294, 2923, 2853, 1695, 1637, 1616, 1543, 1272, 1209, 1071, 1000, 965, $826 \mathrm{~cm}^{-1} ;{ }^{\mathbf{1}} \mathbf{H}$ NMR (DMSO-d 6 ) $\delta=$ 8.46 (br t, 1H, $J=4.6 \mathrm{~Hz}, \mathrm{NH}), 7.92$ (t, $1 \mathrm{H}, J=6.0 \mathrm{~Hz}, \mathrm{NH}), 7.02$ (dd, $1 \mathrm{H}, J=14.9,11.8 \mathrm{~Hz}$ ), $6.68(\mathrm{t}, 1 \mathrm{H}, J=11.8 \mathrm{~Hz}), 6.59(\mathrm{dd}, 1 \mathrm{H}, J=14.9,10.7 \mathrm{~Hz}), 6.22(\mathrm{~m}, 2 \mathrm{H}), 5.95(\mathrm{~d}, 1 \mathrm{H}, J=10.8$ 
Hz), $5.88(\mathrm{ddd}, 1 \mathrm{H}, J=15.1,9.6,5.5 \mathrm{~Hz}), 5.68(\mathrm{dt}, 1 \mathrm{H}, J=14.9,7.0 \mathrm{~Hz}), 5.47(\mathrm{~d}, 1 \mathrm{H}, J=$ $11.6 \mathrm{~Hz}), 5.35(\mathrm{dd}, 1 \mathrm{H}, J=11.3,2.3 \mathrm{~Hz}), 5.21(\mathrm{~d}, 1 \mathrm{H}, J=4.0 \mathrm{~Hz}, \mathrm{OH}), 3.47(\mathrm{~m}, 2 \mathrm{H}), 3.33$ (m, 1H), 2.93 (ddd, 1H, J =13.9, 9.6, $4.2 \mathrm{~Hz}), 2.81(\mathrm{~m}, 1 \mathrm{H}), 2.72(\mathrm{dd}, 1 \mathrm{H}, J=14.9,11.6 \mathrm{~Hz})$, 2.52-2.23 (m, 4H), $2.06\left(\mathrm{q}_{\mathrm{app}}, 2 \mathrm{H}, J=7.0 \mathrm{~Hz}\right), 1.69(\mathrm{~s}, 3 \mathrm{H}), 1.33(\mathrm{~m}, 2 \mathrm{H}), 1.30-1.20(\mathrm{~m}, 8 \mathrm{H})$, $1.00(\mathrm{~d}, 3 \mathrm{H}, J=7.0 \mathrm{~Hz}), 0.85$ (t, 3H, $J=6.8 \mathrm{~Hz}) ;{ }^{13} \mathbf{C}$ NMR (DMSO-d $\left.{ }_{6}\right): \delta=173.5$ (s), 170.3 (s), 165.1 (s), 142.7 (d), 141.2 (d), 136.7 (d), 135.3 (d), 133.1 (d), 133.0 (s), 127.4 (d), 125.7 (d), 125.4 (d), 117.3 (d), 76.2 (d), 72.0 (d), 43.7 (d), 43.5 (d), 39.9 (d), 37.3 (t), 32.3 (2t), 31.2 (t), $29.0(\mathrm{t}), 28.8(\mathrm{t}), 28.6(\mathrm{t}), 22.0(\mathrm{t}), 13.9(\mathrm{q}), 12.8(\mathrm{q}), 12.0(\mathrm{q})$; HRMS (ESI) : Calcd for $\mathrm{C}_{29} \mathrm{H}_{44} \mathrm{O}_{5} \mathrm{~N}_{2} \mathrm{Na}[\mathrm{M}+\mathrm{Na}]^{+}:$523.3142; Found: 523.3144 .

(-)-(13E,15E,17Z)-(2R,7R,8S)-7-Hydroxy-8-methyl-2-[(1E,3E)-1-methylundeca-1,3dienyl]-1-oxa-5,10-diazacyclononadeca-13,15,17-triene-4,9,19-trione $(R-23)$ :

Same procedure as for $(S-\mathbf{2 3})$

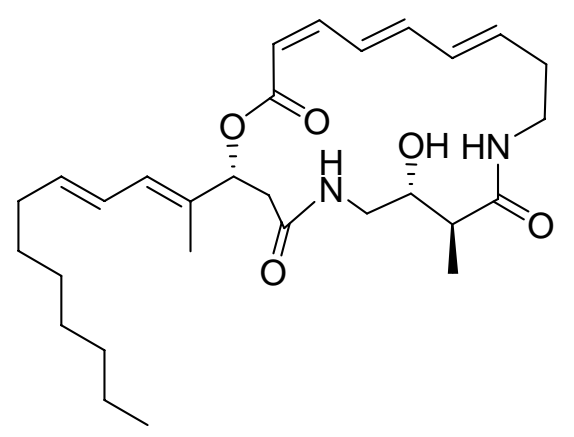

$\boldsymbol{R} \boldsymbol{f} \approx 0.5\left(\mathrm{CHCl}_{3} / \mathrm{MeOH} 90: 10\right) ;[\boldsymbol{\alpha}]^{\mathbf{2 0}}{ }_{\mathbf{D}}-212.9\left(\right.$ c $\left.0.085, \mathrm{CHCl}_{3}\right) ; \mathbf{I R}($ film) : 3314, 2924, $2854,1701,1640,1613,1547,1437,1273,1212,1185,1071,1007,966,827 \mathrm{~cm}^{-1}$; ${ }^{1} \mathbf{H}$ NMR (DMSO-d $)_{\text {) }}: \delta=7.94$ (br m, 1H, NH), 7.74 (br t, 1H, $\left.J=4.6 \mathrm{~Hz}, \mathrm{NH}\right), 7.01$ (dd, $1 \mathrm{H}, J=14.8$, $11.8 \mathrm{~Hz}), 6.64(\mathrm{t}, 1 \mathrm{H}, J=11.8 \mathrm{~Hz}), 6.53(\mathrm{dd}, 1 \mathrm{H}, J=14.8,10.7 \mathrm{~Hz}), 6.33$ (dd, 1H, $J=15.1$, $10.8 \mathrm{~Hz}), 6.23(\mathrm{dd}, 1 \mathrm{H}, J=15.1,10.8 \mathrm{~Hz}), 5.97$ (d, $1 \mathrm{H}, J=10.9 \mathrm{~Hz}), 5.89$ (ddd, $1 \mathrm{H}, J=15.1$, 9.3, 6.2 Hz), 5.68 (dt, 1H, $J=14.9,7.0 \mathrm{~Hz}), 5.46$ (d, 1H, $J=11.5 \mathrm{~Hz}), 5.36$ (dd, $1 \mathrm{H}, J=11.3$, $2.7 \mathrm{~Hz}), 4.79(\mathrm{~d}, 1 \mathrm{H}, J=5.8 \mathrm{~Hz}, \mathrm{OH}), 3.60(\mathrm{~m}, 1 \mathrm{H}), 3.41-3.25(\mathrm{~m}, 2 \mathrm{H}), 3.05(\mathrm{~m}, 1 \mathrm{H}), 2.71$ (dd, 1H, $J=14.5,11.6 \mathrm{~Hz}), 2.59$ (br dt, 1H, J=9.6, 3.7 Hz), 2.44 (m, 2H), 2.32 (m, 1H), 2.18 (br t, 1H, $J=10.6 \mathrm{~Hz}), 2.07$ (qapp, 2H, $J=7.1 \mathrm{~Hz}), 1.71(\mathrm{~s}, 3 \mathrm{H}), 1.34(\mathrm{~m}, 2 \mathrm{H}), 1.30-1.20$ (m, $8 \mathrm{H}), 0.97(\mathrm{~d}, 3 \mathrm{H}, J=7.1 \mathrm{~Hz}), 0.85(\mathrm{t}, 3 \mathrm{H}, J=7.0 \mathrm{~Hz}) ;{ }^{13} \mathbf{C}$ NMR (DMSO-d 6 ): $\delta=173.0(\mathrm{~s})$, 168.7 (s), 165.3 (s), 142.8 (d), 141.4 (d), 137.3 (d), 135.4 (d), 132.9 (d), 131.9 (s), 127.2 (d), 
125.7 (d), 125.5 (d), 117.3 (d), 76.2 (d), 71.3 (d), 44.0 (d), 41.5 (d), 39.9 (d), 37.4 (t), 32.3

$(2 \mathrm{t}), 31.2(\mathrm{t}), 28.8(\mathrm{t}), 28.6(\mathrm{t}), 28.5(\mathrm{t}), 22.0(\mathrm{t}), 13.9(\mathrm{q}), 12.8(\mathrm{q}), 11.1(\mathrm{q})$; SMHR (ESI) :

Calcd for $\mathrm{C}_{29} \mathrm{H}_{44} \mathrm{O}_{5} \mathrm{~N}_{2} \mathrm{Na}[\mathrm{M}+\mathrm{Na}]^{+}$: 523.3142; Found: 523.3145 .

\section{VI- $\quad$ Formal synthesis of FR252921}

(+)-Methyl $(2 E, 4 E, 6 E)-9-\{(2 S, 3 R)-4-[(4 E, 6 E)-(R)-3-h y d r o x y-4-m e t h y l t e t r a d e c a-4,6-$ dienoylamino] 2-methylbutyrylamino\}nona-2,4,6-trienoate (24):

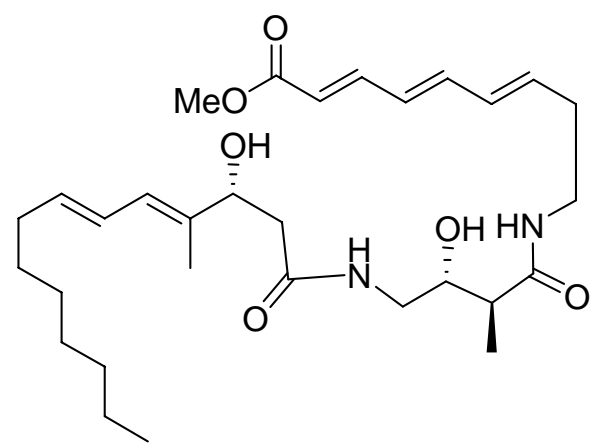

To a stirred solution of carbamate $6(133 \mathrm{mg}, 0.335 \mathrm{mmol}, 1.0$ equiv) in anhydrous $\mathrm{CH}_{2} \mathrm{Cl}_{2}(4 \mathrm{~mL})$ at $0{ }^{\circ} \mathrm{C}$ was added trifluoracetic acid $(1 \mathrm{~mL})$ dropwise. The resulting brown mixture was allowed to warm to rt, and after 45 min of stirring the solution was concentrated in vacuo. The ammomium trifluoroacetate thus obtained was used in the next step without further purification.

To a solution of the ammonium trifluoroacetate previously obtained $(0.335 \mathrm{mmol}, 1.0$ equiv) and carboxylic acid $R-17$ (85 $\mathrm{mg}, 0.335 \mathrm{mmol}, 1.0$ equiv) in anhydrous $\mathrm{CH}_{3} \mathrm{CN}$ (15 $\mathrm{mL}$ ), at $0{ }^{\circ} \mathrm{C}$, were successively added 1-hydroxybenzotriazole $(50 \mathrm{mg}, 0.368 \mathrm{mmol}, 1.1$ equiv), $O$-(1H-benzotriazole-1-yl)- $N, N, N^{\prime}, N^{\prime}$-tetramethyluronium hexafluorophosphate (140 mg, $0.368 \mathrm{mmol}, 1.1$ equiv) and $N$-methylmorpholine (110 $\mu \mathrm{L}, 1.01 \mathrm{mmol}, 3.0$ equiv). The mixture was allowed to reach rt, and after $6 \mathrm{~h}$ of stirring, the resulting brown mixture was hydrolyzed by adding water $(5 \mathrm{~mL}) . \mathrm{CH}_{3} \mathrm{CN}$ was evaporated under reduced pressure and the resulting aqueous layer was extracted with EtOAc $(3 \times 15 \mathrm{~mL})$. The combined organic layers were successively washed with a saturated aqueous solution of $\mathrm{NaHCO}_{3}(15 \mathrm{~mL})$, a saturated aqueous solution of $\mathrm{NH}_{4} \mathrm{Cl}(15 \mathrm{~mL})$ and brine $(15 \mathrm{~mL})$. The organic layer was dried over $\mathrm{MgSO}_{4}$, filtered and evaporated to dryness under reduced pressure. The residue thus obtained 
was purified by flash chromatography on silica gel $\left(\mathrm{CH}_{2} \mathrm{Cl}_{2} / \mathrm{MeOH}\right.$ 95:5) which provided the desired diamide $\mathbf{2 4}$ (138 mg, 78\% over 2 steps) as a yellow foam.

$\boldsymbol{R} \boldsymbol{f} \approx 0.15\left(\mathrm{CH}_{2} \mathrm{Cl}_{2} / \mathrm{MeOH} 90: 10\right) ;[\boldsymbol{\alpha}]^{\mathbf{2 0}}{ }_{\mathbf{D}}+11.2$ (c 1.55, $\left.\mathrm{CHCl}_{3}\right) ; \mathbf{I R}$ (film) : 3305, 2923, 2854, 1717, 1641, 1618, 1546, 1434, 1262, 1234, 1137, 1006, $966 \mathrm{~cm}^{-1} ;{ }^{\mathbf{1}} \mathbf{H}$ NMR (CDCl $\left.\mathbf{3}\right): \delta$ $=7.26(\mathrm{dd}, 1 \mathrm{H}, J=15.2,11.3 \mathrm{~Hz}), 6.93($ br m, 1H, NH), 6.65 (br t, $1 \mathrm{H}, J=5.7 \mathrm{~Hz}, \mathrm{NH}), 6.49$ (dd, 1H, $J=14.8,10.7 \mathrm{~Hz}), 6.21(\mathrm{dd}, 1 \mathrm{H}, J=14.8,11.3 \mathrm{~Hz}), 6.21-6.12(\mathrm{~m}, 2 \mathrm{H}), 6.04(\mathrm{~d}, 1 \mathrm{H}$, $J=11.1 \mathrm{~Hz}), 5.85(\mathrm{~d}, 1 \mathrm{H}, J=15.2 \mathrm{~Hz}), 5.84(\mathrm{~m}, 1 \mathrm{H}), 5.68(\mathrm{dt}, 1 \mathrm{H}, J=14.9,7.0 \mathrm{~Hz}), 4.67$ (m, 1H, OH), 4.41 (br d, 1H, J = 7.0 Hz), 3.95 (br s, 1H, OH), $3.72(\mathrm{~s}, 3 \mathrm{H}), 3.71$ (m, 1H), 3.59 (ddd, $1 \mathrm{H}, J=11.3,7.2,4.1 \mathrm{~Hz}), 3.30$ (m, 2H), 3.01 (ddd, 1H, $J=12.6,7.6,4.7 \mathrm{~Hz}), 2.48-2.26$ $(\mathrm{m}, 5 \mathrm{H}), 2.07\left(\mathrm{q}_{\mathrm{app}}, 2 \mathrm{H}, J=7.1 \mathrm{~Hz}\right), 1.71(\mathrm{~s}, 3 \mathrm{H}), 1.34(\mathrm{~m}, 2 \mathrm{H}), 1.31-1.21(\mathrm{~m}, 8 \mathrm{H}), 1.19(\mathrm{~d}$, $3 \mathrm{H}, J=7.0 \mathrm{~Hz}), 0.86(\mathrm{t}, 3 \mathrm{H}, J=7.1 \mathrm{~Hz}) ;{ }^{13} \mathbf{C}$ NMR (CDCl $): \delta=175.7$ (s), 172.9 (s), 167.6 (s), 144.7 (d), 140.4 (d), 136.0 (d), 135.8 (d), 135.4 (s), 132.0 (d), 128.9 (d), 125.6 (d), 125.5 (d), 120.4 (d), 73.7 (d), 72.9 (d), 51.5 (q), 44.1 (t), 43.7 (d), 41.7 (t), 38.6 (t), 33.0 (2t), 31.9 $(\mathrm{t}), 29.4(\mathrm{t}), 29.2(2 \mathrm{t}), 22.7(\mathrm{t}), 15.5(\mathrm{q}), 14.1$ (q), 12.6 (t); HRMS (ESI) : Calcd for $\mathrm{C}_{30} \mathrm{H}_{48} \mathrm{O}_{6} \mathrm{~N}_{23} \mathrm{Na}[\mathrm{M}+\mathrm{Na}]^{+}$: 555.3405; Found: 555.3409.

$(+)-(2 E, 4 E, 6 E)-9-\{(2 S, 3 R)-4-[(4 E, 6 E)-(R)-3-H y d r o x y-4-m e t h y l t e t r a d e c a-4,6-$ dienoylamino]-2-methylbutyrylamino\} nona-2,4,6-trienoic acid (25):

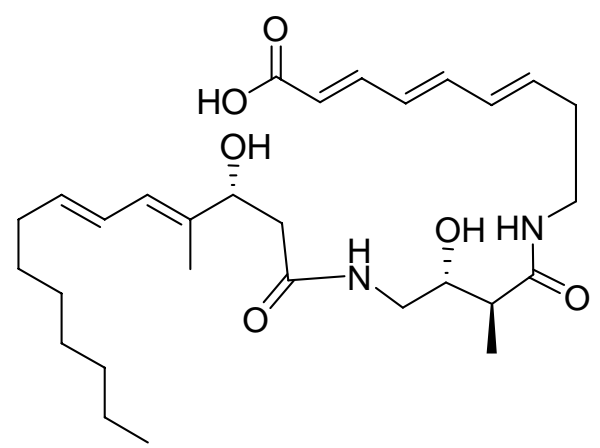

To a stirred solution of trienic ester $24(51.1 \mathrm{mg}, 0.096 \mathrm{mmol}, 1.0$ equiv) in a $\mathrm{THF} / \mathrm{MeOH} / \mathrm{H}_{2} \mathrm{O}$ mixture $(2 / 2 / 1,12.5 \mathrm{~mL})$ was added solid $\mathrm{LiOH}(46 \mathrm{mg}, 1.92 \mathrm{mmol}, 20$ equiv) in one portion at $0{ }^{\circ} \mathrm{C}$ and the resulting yellow mixture was then allowed to reach rt. After stirring for $12 \mathrm{~h}$, the mixture was concentrated under reduced pressure to remove THF and $\mathrm{MeOH}$, diluted with EtOAc $(15 \mathrm{~mL})$ and acidified with a saturated aqueous solution of 
$\mathrm{NaH}_{2} \mathrm{PO}_{4}(\mathrm{pH}=4.5,10 \mathrm{~mL})$. The layers were separated and the aqueous phase was extracted with EtOAc ( $3 \times 10 \mathrm{~mL})$. The combined organic layers were washed with brine $(10 \mathrm{~mL})$, dried over $\mathrm{MgSO}_{4}$, filtered and concentrated in vacuo to provide the corresponding crude carboxylic acid 25 (49.1 mg, 99\%) as a white solid with a satisfying level of purity.

$\boldsymbol{R} \boldsymbol{f} \approx 0.15\left(\mathrm{CH}_{2} \mathrm{Cl}_{2} / \mathrm{MeOH} 90: 10\right) ;[\boldsymbol{\alpha}]^{\mathbf{2 0}}{ }_{\mathrm{D}}+8.8$ (c 1.38, MeOH) $\left\{\mathrm{litt}^{2}[\alpha]^{20}{ }_{\mathrm{D}}+7.7\right.$ (c 1.2, $\mathrm{MeOH})\}$; IR (film) : 3306, 2922, 2853, 1685, 1617, 1551, 1458, 1435, 1364, 1238, 1141, 1006, 965, 886, $675 \mathrm{~cm}^{-1}$; ${ }^{1}$ H NMR (MeOD): $\delta=7.94$ (br t, $1 \mathrm{H}, J=5.8 \mathrm{~Hz}, \mathrm{NH}$ ), 7.89 (br t, $1 \mathrm{H}, J=5.8 \mathrm{~Hz}, \mathrm{NH}), 7.29(\mathrm{dd}, 1 \mathrm{H}, J=15.2,11.2 \mathrm{~Hz}), 6.60(\mathrm{dd}, 1 \mathrm{H}, J=14.9,10.6 \mathrm{~Hz}), 6.32$ $(\mathrm{dd}, 1 \mathrm{H}, J=14.9,11.2 \mathrm{~Hz}), 6.31-6.22(\mathrm{~m}, 2 \mathrm{H}), 6.04(\mathrm{~d}, 1 \mathrm{H}, J=10.8 \mathrm{~Hz}), 5.95(\mathrm{dt}, 1 \mathrm{H}, J=$ 15.1, 7.2 Hz), $5.84(\mathrm{~d}, 1 \mathrm{H}, J=15.2 \mathrm{~Hz}), 5.68(\mathrm{dt}, 1 \mathrm{H}, J=14.9,7.0 \mathrm{~Hz}), 4.43(\mathrm{dd}, 1 \mathrm{H}, J=8.5$, $4.8 \mathrm{~Hz}), 3.71(\mathrm{~m}, 1 \mathrm{H}), 3.42(\mathrm{dd}, 1 \mathrm{H}, J=13.8,4.0 \mathrm{~Hz}), 3.32-3.25(\mathrm{~m}, 2 \mathrm{H}), 3.15(\mathrm{dd}, 1 \mathrm{H}, J=$ 13.8, 7.0 Hz), 2.49-2.33 (m, 5H), 2.11 (qapp, 2H, J=7.0 Hz), 1.75 (s, 3H), 1.39 (m, 2H), 1.34$1.25(\mathrm{~m}, 8 \mathrm{H}), 1.12(\mathrm{~d}, 3 \mathrm{H}, J=7.0 \mathrm{~Hz}), 0.90$ (t, 3H, $J=7.0 \mathrm{~Hz}) ;{ }^{13} \mathbf{C}$ NMR (MeOD): $\delta=177.5$ (s), 174.3 (s), 170.6 (s), 146.6 (d), 142.2 (d), 137.7 (d), 137.3 (s), 136.2 (d), 133.1 (d), 129.8 (d), 127.3 (d), 126.8 (d), 121.6 (d), 75.1 (d), 73.3 (d), 45.4 (d), 44.5 (t), 43.2 (t), 39.7 (t), 34.0 $(\mathrm{t}), 33.9(\mathrm{t}), 33.6(\mathrm{t}), 30.6(\mathrm{t}), 30.3(2 \mathrm{t}), 23.7(\mathrm{t}), 15.2(\mathrm{q}), 14.5(\mathrm{q}), 12.4(\mathrm{t}) ;$ HRMS (ESI) : Calcd for $\mathrm{C}_{29} \mathrm{H}_{46} \mathrm{O}_{6} \mathrm{~N}_{2} \mathrm{Na}[\mathrm{M}+\mathrm{Na}]^{+}$: 541.3248; Found: 541.3257.

\footnotetext{
2 J. R. Falck, A. He, H. Fukui, H. Tsutsui, A. Radha, Angew. Chem. 2007, 119, 4611-4613; Angew. Chem. Int. Ed. 2007, 46, 4527-4529.
} 